San Jose State University

SJSU ScholarWorks

Master's Theses

Master's Theses and Graduate Research

2007

\title{
Spanish and English basic concept knowledge in bilingual preschool children
}

Carolyn M. Artime

San Jose State University

Follow this and additional works at: https://scholarworks.sjsu.edu/etd_theses

\section{Recommended Citation}

Artime, Carolyn M., "Spanish and English basic concept knowledge in bilingual preschool children" (2007). Master's Theses. 3451.

DOI: https://doi.org/10.31979/etd.4hfx-ntcr

https://scholarworks.sjsu.edu/etd_theses/3451

This Thesis is brought to you for free and open access by the Master's Theses and Graduate Research at SJSU ScholarWorks. It has been accepted for inclusion in Master's Theses by an authorized administrator of SJSU ScholarWorks. For more information, please contact scholarworks@sjsu.edu. 
SPANISH AND ENGLISH BASIC CONCEPT KNOWLEDGE IN BILINGUAL PRESCHOOL CHILDREN

\author{
A Thesis \\ Presented to \\ The Faculty of the Department of Communication Disorders and Sciences \\ San José State University
}

\author{
In Partial Fulfillment \\ of the Requirements for the Degree \\ Master of Arts
}

by

Carolyn M. Artime

December 2007 
UMI Number: 1452078

Copyright 2007 by

Artime, Carolyn M.

All rights reserved.

\section{INFORMATION TO USERS}

The quality of this reproduction is dependent upon the quality of the copy submitted. Broken or indistinct print, colored or poor quality illustrations and photographs, print bleed-through, substandard margins, and improper alignment can adversely affect reproduction.

In the unlikely event that the author did not send a complete manuscript and there are missing pages, these will be noted. Also, if unauthorized copyright material had to be removed, a note will indicate the deletion.

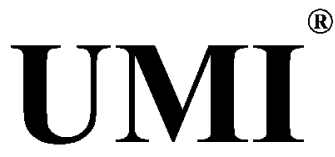

UMI Microform 1452078

Copyright 2008 by ProQuest LLC.

All rights reserved. This microform edition is protected against unauthorized copying under Title 17, United States Code.

ProQuest LLC

789 E. Eisenhower Parkway

PO Box 1346

Ann Arbor, Ml 48106-1346 
(C) 2007

Carolyn M. Artime

ALL RIGHTS RESERVED 
APPROVED FOR THE DEPARTMENT OF EDUCATION

Yeuneterw. Sanguear

DPed drungtwo

Diplioria Weddingtoon

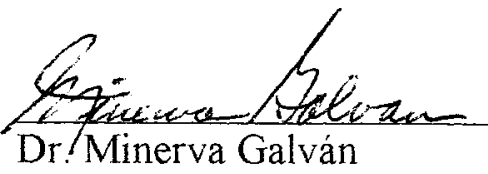

APPROVED FOR THE UNIVERSITY

Shen I. Whaman 11/21/2007 


\section{ABSTRACT \\ SPANISH AND ENGLISH BASIC CONCEPT KNOWLEDGE IN BILINGUAL PRESCHOOL CHILDREN \\ by Carolyn M. Artime}

This study investigated 22 bilingual preschool children's performance on the Wiig Assessment of Basic Concepts (WABC) Spanish and English versions. The participants communicated in Spanish at home with at least $30 \%$ frequency. A qualitative analysis examined the detected concept knowledge and corresponding categories of three groups of children: students performing in the average range on the WABC Spanish version, children performing in the average range on the WABC English version, and the seven lowest performing children on both versions of the test.

The study's results supported Cummins' theory that children with a stronger first language (L1) foundation acquire a second language (L2) more efficiently. In addition, the research completed demonstrates the importance of testing bilingual children in both their L1 and L2 in order to accurately assess their basic concept knowledge. 


\section{ACKNOWLEDGMENTS}

I would like to thank all of the individuals who supported and guided me during the process of completing the thesis. I am very appreciative of the teachers, the children and their parents who participated and made this project become a reality. I would like to thank my thesis committee, Dr. Gloria Weddington and Dr. Galván, for their comments, and Dr. Langdon for her positive feedback while designing and implementing the research. I would also like to thank my family and friends for their understanding and encouragement throughout the progression of the project. 


\section{TABLE OF CONTENTS}

CHAPTER

I. INTRODUCTION

Background 1

Problem Statement 3

Purpose Statement $\quad 4$

Research Questions $\quad 5$

Definitions of Terms 6

$\begin{array}{ll}\text { Assumptions } & 7\end{array}$

$\begin{array}{ll}\text { Limitations } & 8\end{array}$

$\begin{array}{ll}\text { Delimitations } & 8\end{array}$

$\begin{array}{lr}\text { Significance Statement } & 8\end{array}$

II. REVIEW OF LITERATURE

$\begin{array}{ll}\text { Introduction } & 10\end{array}$

History of Bilingual Education $\quad 13$

Concept Development in Monolingual Children $\quad 17$

Cross- linguistic Aspects in Concept Development 20

Concept Development in Bilingual Children: 22

Impact on Academic Success

Thresholds Theory: Optimal Learning of L2 23

Concept Knowledge 
Developmental Interdependence Hypothesis:

Optimal Learning of L2 Concept Knowledge

Factors Influencing Successful Bilingual Language 28

Acquisition

Why Assess in Two Languages?

III. METHODOLOGY

Background

Participants

Instruments

Procedures

Confidentiality

IV. RESULTS AND DISCUSSION

Background

Data Analysis

V. SUMMARY, CONCLUSIONS, RECOMMENDATIONS

Summary

Conclusions

Recommendations

REFERENCES

APPENDIX A

Parent Questionnaire

Teacher Questionnaire 
Concept Knowledge of 13 Children Performing in 77 the Average Range in Spanish

Concept Knowledge of 7 Children Performing in 79 the Average Range in English

Concept Knowledge of 7 Lowest Performing

Children 


\section{List of Tables}

Table 4-1: Number of Children Performing in the Average Range 40

Table 4-2: Number of Children Answering With at Least 50\% or $80 \%$ Accuracy 41

Table 4-3: Concepts and Categories Comprehended/Expressed in Spanish and

English by at least $80 \%$ of Average Scoring Students on the WABC (Spanish)

Table 4-4: Concepts and Categories Comprehended/Expressed in Spanish, but

Only Comprehended in English by at least $80 \%$ of Average Scoring

Students on the WABC (Spanish)

Table 4-5: Concepts and Categories Comprehended/Expressed in Spanish, but

Not Comprehended/Expressed in English by at least $80 \%$ of Average

Scoring Students on the WABC (Spanish)

Table 4-6: Concepts and Categories Comprehended/Expressed in English and Spanish by at least $85 \%$ of Average Scoring Students on the WABC (English)

Table 4-7: Concept and Category Comprehended/Expressed in English but Only Comprehended in Spanish by at least $85 \%$ of Average Scoring Students on the WABC (English)

Table 4-8: Concept and Category Comprehended/Expressed in English, but Not Comprehended/Expressed in Spanish by at least $85 \%$ of Average Scoring Students on the WABC (English)

Table 4-9: Concepts and Categories Not Comprehended/Expressed in Either Language by at least $80 \%$ of Average Scoring Students on the WABC Spanish

Table 4-10: Concepts and Categories Not Comprehend/Expressed in Either Language by at least $85 \%$ of Average Scoring Students on the WABC (English) 


\section{Chapter I}

Introduction

\section{Background}

On June 2, 1998, 61\% of California voters approved Proposition 227, which implemented English-only instruction in California public school classrooms; specifically preschool through the high school level. Ron Unz, a wealthy software developer, formulated Proposition 227 and titled it, "English for the Children" (Crawford, 2000, p. 106). The California Education Code, Section 306, defines an English Learner (EL) as “a child who does not speak English or whose native language is not English and who is not currently able to perform ordinary classroom work in English" (California Department of Education: Reclassification, 2007, p. 1). Unz and his supporters believed that bilingual education did not give children who are ELs the opportunity to quickly learn English, since instruction was not solely provided in that language. Given that EL students compose at least one-third of youngsters beginning the first grade in California, Proposition 227 is affecting the learning of a large proportion of students attending the California public school system (Crawford, 2000).

Unz's proposition was approved at a time when Los Angeles parents at Ninth Street Elementary School protested their children's placement in bilingual programs. The parents wanted to withdraw their students from the programs, since they believed that their children's English language development was not progressing. The proposition passed based upon the premise that children who speak English as a second language 
(L2) should have the opportunity to learn English as quickly as possible in the public schools. Unz supporters equated learning English quickly with students entering Englishonly classrooms. However, Unz's initiative promoting " sheltered English immersion... not normally intended to exceed one year" (Crawford, 2000, p. 112) for students entering the public schools with English as their L2 contradicts research and evidence-based practice regarding the most effective manner to learn a second language. Rather, Proposition 227 is a reflection of a certain group's ideology. This is not surprising given that throughout the history of bilingual education in the United States, policies have been driven by the sentiment of the government and public regarding a multilingual society as opposed to research related to bilingualism.

As noted by Langdon (2008), the U.S. has traveled through four phases in dual language education policy, which include the permissive, restrictive, opportunist, and dismissive periods. The various attitudes adopted in each phase reflect the nation's political and social issues associated with each time period. Although research-based legislation has not been at the forefront of bilingual education policy, research has been completed regarding the best conditions and approximate timelines necessary for students to learn a second language at various proficiency levels.

According to Cummins' (1979) Developmental Interdependence hypothesis, “... the development of competence in a second language (L2) is partially a function of the competency already developed in the first language (L1) at a time when intensive exposure to L2 begins" (p. 222). This model holds true for both typically developing individuals, and those with speech and language delays and disorders (Perozzi \& Chávez 
Sánchez, 1992). Furthermore, Cummins studied the time period necessary to develop Basic Interpersonal Communication Skills (BICS) and Cognitive Academic Language Proficiency (CALP). Theoretically, BICS necessitates approximately 1 to 3 years to develop and CALP requires roughly 5 to 7 years (Cummins, 1981, 1984).

\section{Problem Statement}

Escamilla (1994) reported that 'Half of all students who have been labeled limited English proficient (LEP) are in classrooms where no special services are provided for them, not even a minimal pull-out ESL' (Escamilla, 1994, p. 3; Linguistic Minority Research Institute, 2003). When ELs are solely tested in English, the students' test scores may not adequately reflect their knowledge. Specifically, in order to examine EL youngsters' concept knowledge, it is necessary to test the native/primary and secondary languages, so that comprehension and expression in both languages can be assessed (Peña, 2001; Peña, Bedore, \& Rapazzo, 2003). When this process is followed, EL students can receive additional support as mandated by the No Child Left Behind (NCLB) Act (No Child Left Behind, 2007, p.9). The following quote explains the nature of this support:

"More attention will be focused on English language acquisition as the foundation for academic achievement. To acknowledge the close relationship between the development of English language proficiency and academic content proficiency, as well as to create incentives to accelerate the learning of English, state accountability systems will include a provision to recognize schools making significant progress in moving LEP students toward English language proficiency (p. 9)."

However, after reviewing research regarding second language acquisition, Proposition 227 does not aid students in efficiently learning English as the NCLB Act calls for. For example, in California public schools, when EL students are only tested in 
English, they may perform poorly due to a lack of English language proficiency, and their true academic strengths and needs may not be identified or can be misidentified. Bilingual students should be tested in both L1 and L2, so their knowledge in both languages can be evaluated. By following this procedure, ELs can receive the appropriate instruction necessary to reach their academic potential.

For example, when preschool children coming from Spanish-speaking homes enter classrooms where instruction is conducted in English only, students' basic concept knowledge should be tested in both English and Spanish in order to obtain an accurate baseline assessment of their ability in each language. If the children's basic concept knowledge is not probed in both languages, instruction may not be tailored to their specific needs. Additionally, when bilingual students are not tested in L1 and L2, they may be misidentified as having language and/or learning disabilities. In order to accurately identify students with language disorders or learning disabilities, testing in L1 and L2 is essential to determine if students perform poorly in both languages.

\section{Purpose Statement}

The purpose of this study was to examine the comprehension and expression of basic concepts of typically developing preschool students who come from Spanishspeaking home environments and who are attending preschools where English is the primary instructional language. Both the English and Spanish Wiig Assessment of Basic Concepts (WABC) (Wiig, 2004; Wiig \& Langdon, 2006) were utilized to compare bilingual preschool children's knowledge of concepts in the two languages. Parent and 
teacher questionnaires were completed to learn about the children's home language environment and performance in school.

The results of the study were intended to delineate each student's basic concept knowledge strengths and needs. The information gathered from the study was provided to parents and teachers to enable them to reinforce the understanding and application of important concepts that are fundamental for the children's further language and academic development.

Research Questions

1- Is there a difference between EL children's detected concept knowledge in Spanish in comparison to English when children communicate in Spanish with family members, relatives and neighbors with at least $30 \%$ frequency?

2- What are the concepts understood and expressed in both Spanish and English, or in Spanish only by students who performed in the average range on the WABC Spanish version? In addition, the concepts identified by the WABC that this group of students comprehended yet did not express in English will be reported.

3- What are the concepts understood and expressed in both English and Spanish, or in English only by students who performed in the average range on the WABC English version? Additionally, the concepts identified by the WABC as comprehended but not expressed in Spanish will be reported.

4- Which concepts were not comprehended or expressed by students performing in the average range on the WABC Spanish version? The same analysis will be conducted for students who performed in the average range on the WABC English version. 
5- Finally, which concepts were not understood or expressed by the lowest performing group on both versions of the WABC?

Definitions of Terms

Additive bilingualism- implies a community that promotes multilingualism in its national policies regarding immigration and education; in this scenario, a second language adds to one's home language and culture.

Balance Effect- a theory about bilingual concept development suggesting that as a child learns a second language, L1 development and proficiency decrease.

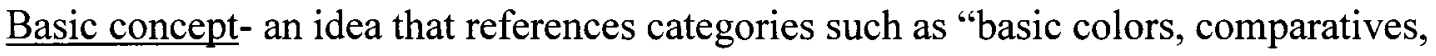
directions, materials, positions, quantities, relationships, sequences, shapes, sizes, social or emotional states and characteristics, textures, and time" (Bracken, 1998, p. 7).

Basic Interpersonal Communication Skills (BICS)- the ability to hold a context- based conversation; under ideal conditions, this ability develops in 1 to 3 years for an individual who is in the process of acquiring a second language (Cummins, 1981).

Cognitive Academic Language Proficiency (CALP)- the ability to use abstract language in academic scenarios by an individual who is acquiring a second language; this skill may require 5 to 7 years to develop (Cummins, 1984).

Common Underlying Proficiency Model- (CUP) the first model to propose that concept knowledge interacts between L1 and L2 (Cummins, 1981).

Code-switching- a rule-based manner of utilizing two languages used by bilinguals; codeswitching depends on the topic and environment and occurs for various purposes (i.e. to emphasize a word or to show affiliation with a group). 
Developmental Interdependence hypothesis- children must possess enough learning in L1 before the most efficient L2 learning can occur (Cummins, 1979).

English Language Learner (ELL) or English Learner (EL)- an individual who is learning English as a second language.

L1- a person's native or first language acquired.

L2- a person's second language acquired.

Primary/Dominant Language- the language spoken with greatest frequency; one may not have the greatest competency in the dominant language, however (Langdon, 2008). Separate Underlying Proficiency Model of Bilingualism- (SUP) a model of bilingualism that postures that L1 and L2 do not interact in a bilingual's brain (Cummins, 1980).

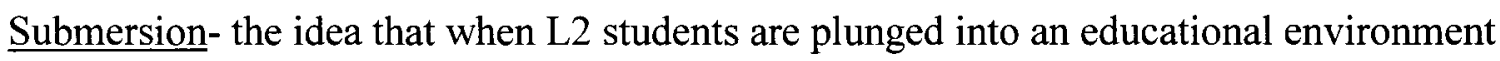
where instruction is only in L1, they will consequently perform adequately or struggle academically (Baker, 2006).

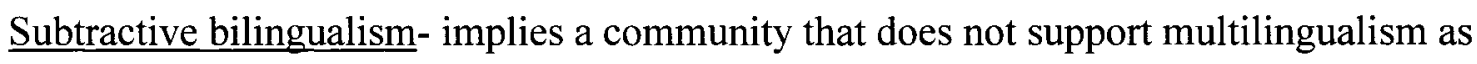
reflected in its national policies regarding immigration and education; acquisition of a second language replaces the first language and the culture associated with the home language (Baker, 2006).

Thresholds Theory- bilingual children must reach a certain level of proficiency in L1 and L2 before they can obtain the benefits of bilingualism (Cummins, 1977).

Assumptions

In order to conduct this research, this study assumed that: 
Parents and teachers of the participants would promptly complete the provided questionnaires.

Parents and teachers would respond to the survey to the best of their ability.

The participants completed the WABC in English and Spanish to the best of their ability.

\section{Limitations}

In order to conduct this study, the following limitations were beyond the control of the research design:

Some participant households chose not to complete the parent questionnaire in its entirety.

Some participants' personalities may have hindered them from answering all of the questions within their ability.

\section{Delimitations}

Although EL students attend school from the preschool through the high school level, the present study focused on 4 and 5 year old preschool children.

Although EL students have varying home language experience, the present study focused only on students with at least $30 \%$ frequency of home communication in Spanish.

Although EL students speak numerous languages nationwide, the present study only focused on students who speak Spanish as their L1 and are learning English as their L2. 


\section{Significance Statement}

Completing this study will provide parents and teachers with information about the basic concept knowledge in English and Spanish that the participants possess. This information can be used to teach the children the basic concepts that they have not yet learned. Parents can reinforce their children's basic concept needs in the home, while teachers can do so at school. Thus, the students will be better prepared for kindergarten. 


\section{Chapter II}

Review of Literature

\section{Introduction}

As early as 1953, the United Nations Educational, Scientific, and Cultural Organization (UNESCO) stated that, optimally, teachers should provide instruction in a child's home language for as long as possible. This approach enables children to acquire literacy and gain academic knowledge because they are accustomed to experiencing the world in that language (Brisk, 2006). Bilingual programs in the United States were instituted following the Bilingual Act of 1968 and lasted for approximately 20 years. However, the implementation of these programs lost support following a long debate regarding their effectiveness in assuring successful acquisition of the English language and improved academic performance. For details, the reader is referred to Crawford, 2000.

Thirty years later, in 1998 , taking advantage of a political climate when teaching in another language (primarily in Spanish) was viewed as ineffective, Ron Unz persuaded voters in California to pass his initiative, Proposition 227. This legislation established that English Learners (ELs) in California will "learn English by being taught in English" (Baker, 2006, p. 196). As a result of the proposition, ELs were permitted to only attend immersion classrooms for up to 1 year and subsequently needed to enter mainstream English-speaking classrooms. This practice has been implemented at the K-12 level and is followed at the preschool level as well. 
The current California approach to instruct EL students in English-only programs may not be an efficient way to promote language and academic success as reported in research studies. Specifically, Thomas and Collier $(1997,2002)$ found that the least effective method in instructing EL students was to only offer English as a Second Language (ESL) support instead of providing these students with the opportunity to attend dual immersion programs, maintenance or transitional programs.

Nationwide, Hispanic student enrollment in public elementary schools has risen approximately $150 \%$ during the past 20 years. By 2025 , it is projected that Hispanics will comprise roughly $25 \%$ of school-age students. In addition, in the United States, approximately $75 \%$ of ELs are Hispanic; the largest proportion of English Learners in the public schools (Padrón, Waxman \& Rivera, 2002, p. 2).

During the 2005 to 2006 school year, in California public schools, approximately one third or 1.3 million EL students spoke a language other than English as their primary language. Of those students, $85.4 \%$ spoke Spanish as their primary language. When the language background of the remainder of EL students is analyzed, $14.6 \%$ spoke 1 of 100 other languages, with Vietnamese being the second most frequently spoken language (Statewide English Learners by Language and Grade). Hispanic EL students compose a large student population in California public schools, and are the second largest group (following socioeconomically disadvantaged students) to drop out of high school. Specifically, English Learners comprised $31.7 \%$ or 22,767 of 71,916 high school dropouts (Statewide Dropout Reports 2005-2006). During the 1998 to 1999 school year, the year Proposition 277 came into effect, the California Department of Education did not 
maintain a list of dropouts by program (including the English Learner program). However, during that school year, $51.08 \%$ of the dropouts were Hispanic or Latino (Statewide Dropout Reports 1998-1999). More recently, during the 2005 to 2006 school year, 40,080 (55.73\%) of high school dropouts were Hispanic. Therefore, subsequent to Proposition 227 being implemented, more Hispanics have dropped out of high school.

In light of Hispanics struggling to succeed academically, some believe that learning English as a second language (L2), and instruction in languages other than English is to blame for many students' academic shortcomings. However, the statistics regarding Hispanics' academic achievement suggest that Proposition 227 is not aiding EL students to succeed in school. The solutions included in Proposition 227 are not based on research regarding the time period and process that occurs when one learns a second language. Research-based guidelines regarding second language learning follow.

One should consider that under most favorable conditions, Basic Interpersonal Communication Skills (BICS) or conversational performance and Cognitive Academic Language Proficiency (CALP) (more abstract use of language to learn academic material) develop in approximately 1 to 3 , and 5 to 7 years, respectively (Cummins, 1981, 1984). Even though the dichotomy between the two different language uses was conceptualized more than 25 years ago, researchers and educators continue to refer to this model. Therefore, when monolingual Spanish-speaking children or speakers of another language are placed in English submersion classrooms, their test scores in English may reflect less concept knowledge than the children actually possess. 
The literature review includes four sections. The first section offers a brief review of bilingual education history to understand the significance of assessing proficiency in the child's first language (L1). Research on monolingual and bilingual concept development is discussed in the second section. The third section outlines theories and teaching methodologies for successful second language acquisition. Finally, the importance of assessing bilingual individuals in both their first and second languages is discussed in the fourth section. History of Bilingual Education

Historically, bilingual education policy in the United States and dual language instruction have been viewed either favorably or with reluctance depending on the political climate of the times. Four different phases in bilingual education policy may be identified: the permissive, restrictive, opportunist, and dismissive periods (Langdon, 2008). In general, between 1774 and the commencement of World War I, the United States experienced a permissive period in regard to immigration. The use of various languages was accepted. When European immigrants began settling in the United States, Native American tribes spoke more than 300 indigenous languages. The Europeans sometimes taught using indigenous languages in order to facilitate the conversion of Native Americans to Christianity. Multilingualism existed in the media and educational system, and federal as well as state governments took no action to impede the use of various languages in schools and communities. Aberrations to this general trend did exist, however. In 1855, California implemented an English-only policy for educational 
instruction, and in the 1880s, the Bureau of Indian Affairs aimed to impede the use of indigenous languages (Baker, 2006; Brisk, 2006; Crawford, 2000).

During this first era in bilingual (dual language) education, bilingual schools reflected the various rural enclaves of immigrants who were settling in the United States. In the mid $19^{\text {th }}$ century, German immigrants implemented the first German-English schools. Other languages involved in bilingual education included Polish, Italian, Dutch, and Danish. In urban areas, the majority of instruction occurred in English. However, bilingual schools whose teachers instructed in both German and English existed in Cincinnati, Baltimore, San Francisco, and Denver (Baker, 2006; Brisk, 2006; Crawford, 2000).

A change in U.S. attitudes toward immigrants and bilingual education began around 1900 to 1920 . This restrictive period spanned from the end of the $19^{\text {th }}$ century until the 1950's. A large wave of immigration occurred during this time period, and a trend toward Americanizing the newcomers emerged. The 1906 Nationality Act required individuals to have some knowledge of English to gain citizenship. In 1917, the United States entered into World War I. Anti-German attitudes resulted in the elimination of German-English bilingual education. The common sentiment was that in order to become an American, it would be necessary to abandon one's native language in order to adopt English. In 1919, the Americanization Department of the United States Bureau of Education strongly encouraged all states to conduct school instruction solely in English. Consequently, only five years later, in 1923, 34 states required that all elementary school instruction occur in English (Baker, 2006; Brisk, 2006). 
In 1957, scientific advances led to a change in U.S. policy toward multilingualism, and the nation entered an opportunist period in relation to bilingualism that spanned from the 1960 s until 1980. The Russians launched Sputnik which prompted the U.S. government to pass the 1958 National Defense and Education Act. This legislation implemented foreign language instruction in the schools. The Civil Rights Movement in the 1960s influenced the U.S. population's attitudes regarding educating ELs by introducing sentiments of tolerance in regard to various ethnic groups. In 1963, Cuban exiles organized the first dual language school, Coral Way Elementary, in Miami, Florida. This school paved the way for future bilingual education programs.

The 1968 Bilingual Education Act, Title VII, an amendment to the 1965 Elementary and Secondary Education Act, stated that education policy at the national level needed to include bilingual education programs. The various intents of the act included implementing dual language instruction, and the maintenance of foreign language resources in the United States (Langdon, 2008). Overall, this act mandated allocating federal funding toward educating ELs (Baca \& Cervantes, 2004; Brisk, 2006; U.S. Code Title 20, 1968). However, the Bilingual Education Act lacked clear standards regarding the implementation of bilingual education programs. Therefore, models varied in structure and efficacy and consequently did not receive widespread societal support.

In 1970, Chinese students faced the San Francisco Board of Education in the Lau versus Nichols case. The case addressed the constitutionality of non-English speaking students receiving instruction in English-only schools. The verdict eliminated the practice of placing ELs in mainstream, English-speaking classrooms. The Lau Remedies 
mandated placing students in English as a Second Language classrooms, providing them with tutoring in English, and the creation of some bilingual education programs (Baca \& Cervantes, 2004; Brisk, 2006).

The 1974 Bilingual Education Act, as amended, was the first legislation to give schools grants for teachers to provide instruction in students' native languages. This legislation allowed students to progress academically in either English or their native language. However, the 1978 Transitional Bilingual Education legislation reversed the 1974 amendments and solely allowed students to receive education in their native language in order to transition to English-only classrooms (Baker, 2006).

In bilingual education, the dismissive period spans from 1980 to the present. The Reagan administration revoked the Lau Remedies and impeded the progress of bilingual education. President Ronald Reagan's stance was that bilingual education hindered ELs from ultimately learning English and succeeding in the job market. In 1983, Baker and de Kanter reported that bilingual education had a negative impact on the academic achievement of Hispanic EL students. The team concluded that insufficient evidence exists to promote maintenance of students' native languages, and that the goal of bilingual education should be to quickly transition students from L1 to L2. The researchers promoted local control of bilingual education as opposed to federal control. Consequently, local politicians were put in charge of creating laws to enact bilingual education programs (Baker, 2006).

Federal changes in favor of bilingual education did not occur until the Clinton era and Goals 2000, the Educate America Act, and the Improving America's Schools Act. 
The aforementioned legislation recognized the importance of providing quality education to ELs. Title VII was reenacted. However, it did not receive the same amount of funding as in previous years; an indicator of the degree of importance the administration placed on bilingual education (Baker, 2006).

In 1998, California passed Proposition 227 which instated English-only instruction for the purpose of aiding ELs to learn English rapidly. Unfortunately, this legislation does not follow the recommendations of research regarding effective second language learning (Cummins, 1979; Huguet, Vila, \& Llurda, 2000; Perozzi, 1985;

Perozzi \& Chávez Sánchez, 1992; Thomas \& Collier, 1997, 2002). Richard W. Riley, the U.S. Secretary of Education, expressed his disapproval of the proposition. In 2001, the No Child Left Behind Act (NCLB) reauthorized the Bilingual Education Act for six years. This legislation emphasizes the importance of annually assessing the academic level of ELs in the areas of reading, writing, and oral language. Title III of NCLB places the onus on states to promote bilingual education and removes the federal government from having a direct role. States must have specific plans regarding how they will accommodate ELs in their school systems. Schools must implement programs that are based on evidence-based research (Baca \& Cervantes, 2004; Baker, 2006). Concept Development in Monolingual Children

Adequate concept knowledge correlates with children's future academic achievement (Bracken, 1998; Ellis, Schlaudecker \& Regimbal, 1995; Seifert \& Schwartz, 1991). Bracken (1998) defined a basic concept as a word that references categories such as "basic colors, comparatives, directions, materials, positions, quantities, relationships, 
sequences, shapes, sizes, social or emotional states and characteristics, textures, and time" (p. 7). Research has shown that teachers use basic concepts frequently while giving students instruction. Therefore, sufficient basic concept knowledge aids children with following directions in the classroom setting. Adequate basic concept knowledge has also been indicative of future reading success (Seifert \& Schwarz, 1991).

As children play and interact with their parents and caregivers, they use language to express what is occurring in their environment (Peña et al., 2003; Peña, Bedore, \& Zlatic-Giunta, 2002). Kohnert (2004) explains that as monolingual children learn language, they travel through two stages of language development. In the first stage, children explore their environment and connect referents with lexicon. Their vocabulary is more likely to include words referring to moving objects (e.g. a car) as opposed to stationary objects.

Different theories exist regarding the order in which children acquire basic concepts. Piaget's theory of cognitive development proposes that children should be cognitively "ready" to acquire different types of information during various age ranges. Piaget's stages of cognitive development outline a child's cognitive growth and may account for a child's ability to understand and express different concepts. The following two stages pertain to the present study. The children included in the study are in the preoperational stage ( 2 to 7 years old). According to Piaget, during this period, children gain the ability to represent objects in their environment using language, and consequently children's language abilities expand. Subsequently, when children are between 7 and 11 years of age, they enter the concrete operational stage of development. During this time 
span, children acquire the concept of conservation that pertains to seven areas:

specifically, number, length, liquid, mass, weight, area, and volume. Therefore, concepts tested in the WABC related to the aforementioned areas may be difficult for children whose ages range from 4 to 5 to acquire (Piaget $\&$ Inhelder, 1956).

Researchers have suggested varying ways children organize learned concepts. Some believe that an object's function is the primary determiner when children group objects. In this scenario, children group objects "thematically" (Nelson \& Nelson, 1990; Peña et al., 2003); groups may include food that one eats for dinner, for example. In this scenario, children learn the relationship between objects and their functions, which aids them in the formation of "slot-filler categories for various concepts" (Peña et al., 2002, p. 939).

Other researchers believe that children group concepts according to "superordinate categories" (Nelson \& Nelson, 1990; Peña et al., 2003; Peña et al., 2002) for example, fruit and vegetables. In this scenario, the likeness and differences among various objects determine how children organize items in their mental schema. Furthermore, according to Gleason (2001), children may learn "prototypes or core concepts" (p. 128) specific to various categories. For example, an apple may be a prototype for the fruit category. In order to categorize properly, youngsters must learn that particular features correspond to objects in a group. A child may learn that members of the fruit category can be eaten, are sweet, and grow outside.

Furthermore, while learning the concepts that correspond with various categories, children must decipher between "classical" and "probabilistic concepts" (Gleason, 2001, 
p. 129). Classical concepts consistently possess the same features. For example, a square must have four equal sides. A probabilistic concept (such as a dog) has slightly more ambiguous features. Dogs come in different sizes and colors depending on their breed or mix. When learning which concepts belong to specific categories, children must mentally organize the features that cause an object to belong to a given category.

In summary, when children are learning basic concepts, they are categorizing items by examining objects' similarities/differences, functions and features. Kohnert (2004) explains that the categorization process becomes more rapid in the second stage of language development. Therefore, children can more quickly process previously categorized linguistic knowledge.

\section{Cross- linguistic Aspects in Concept Development}

When a child is learning language, early developing concepts depend upon the vocabulary that varying cultures and languages emphasize. According to Peña et al. (2003), three factors influence children's vocabulary development: “... developmental order of concepts, lexical frequency, and conversational focus in the language or languages being learned" (p. 8). In regard to the first factor, children's learning of the sequence and rapidity of linguistic structures differs according to the language being learned. In regard to the second factor, some languages emphasize certain words more than others. In regard to the third factor, some cultures/languages may place more emphasis on the meaning of verbs as compared to nouns. Therefore, an emphasis on teaching verbs would precede caregivers teaching nouns. Thus, cultural preferences for 
vocabulary instruction affect children's development of concepts and vocabulary (Peña et al., 2003).

Furthermore, children use languages in different contexts and social situations. Each child's pattern of language use determines his/her vocabulary growth in each language. The home and school are two contexts where children learn and utilize different vocabulary. In the home, children may interact among themselves in English. They may speak Spanish with their parents when discussing the day's events, eating a meal, or doing household chores. However, children and parents may communicate in English when they are completing homework assignments together.

Children also acquire the patterns of code-switching that occur in their communities. Code-switching or "alternating languages" (Langdon, 2008, p. 27) does not reflect a lack of proficiency in a language. It may occur when a child possesses a concept, yet has not learned the vocabulary for that concept in a language (their L2, for example) (Genesee, 2001). However, code-switching may occur despite the fact that children know the vocabulary for the concept they are expressing in both L1 and L2. These children may code-switch because they are aware that their listener knows both languages (Baker, 2006).

Individuals often experience a shift in language proficiency over time. It is common for persons with Spanish as their L1 to initially possess greater proficiency in Spanish, and then during the later school age years develop greater proficiency in English. Individuals who possess Spanish as their L1 and English as their L2 may 
become balanced bilinguals in that over time they can become similarly proficient in both languages (Kohnert, 2004; Langdon, 2008; Patterson \& Peterson, 2004). Concept Development in Bilingual Children: Impact on Academic Success

Researchers have proposed various theories regarding bilingual children's concept learning and storage. Early ideas about bilingual concept development alluded to a 'balance effect' (Cummins, 1977, p.4) when one learns two languages. As a child adds more concept knowledge to the second language (L2) scale, the first language (L1) scale is neglected. Other theories referred to a balloon analogy in that the monolingual brain possesses one fully-inflated balloon containing concept knowledge. The bilingual brain, however, contains two smaller balloons or allotted spaces for each language. Less space is available for the development of either L1 or L2. Therefore, the full development of both languages is jeopardized. Cummins named this model the Separate Underlying Proficiency (SUP) model of bilingualism (Cummins, 1980). In the two aforementioned analogies, concepts between L1 and L2 do not interact in the bilingual's brain.

\section{Cummins' Common Underlying Proficiency (CUP) model of bilingualism was} the first to explain that bilingual cognitive processing, specifically concept knowledge, interacts between L1 and L2 (Cummins, 1981). When conversing, bilinguals utilize different grammatical structures, phonology, and morphology depending on the language spoken. However, there is a single thought and a decision made whether to use L1 or L2 that drives the outward manifestation of the language spoken or written. In addition, Cummins emphasized that bilinguals have the ability to learn in either L1 or L2. The material learned in both languages is integrated into the common processing system. 
However, if a child's L2 has not developed to a certain level, s/he may be unable to effectively integrate classroom knowledge into the common processing system. This affects ELs in California who attend classes in their L1 for one year, and subsequently enter classrooms where L2 is the sole language used (Baker, 2006; Gutiérrez-Clellen, 1999).

Peña et al. (2002) studied the manner in which bilinguals organize concepts. According to the researchers, children use slot-filler categories to organize concepts and objects related to the variety of experiences that they encounter. For example, chicken is a slot-filler in the category, foods I eat for dinner. Children who speak and listen to different languages may organize objects in distinct slot-filler categories depending upon their experiences with each language. For example, a child may communicate about equally in Spanish and English at home while another child may only communicate in Spanish at home and English at school. Therefore, presenting these children with questions about a variety of categories in Spanish and English may not result in the same answers (Peña et al., 2002). Children in the present study were Spanish-speaking, and receiving instruction in English. They speak Spanish and English with varying frequencies in the home. Therefore, when tested in Spanish and English, different levels of concept comprehension/expression may be detected in each language.

\section{Thresholds Theory: Optimal Learning of L2 Concept Knowledge}

The Thresholds Theory explains that children must reach a certain level of proficiency in their first and second languages in order for them to fully comprehend and apply academic material in both L1 and L2 (Cummins, 1977). Therefore, when 
instruction is provided in students' L2, children who do not possess sufficient knowledge in that language may suffer poor academic performance. These consequences are more likely to occur when a child's L2 is the language of the majority culture; for example, native Spanish-speaking children entering submersion classrooms in which English is the sole language of instruction. These children must attain a certain level of L1 and L2 proficiency before they can reap the cognitive benefits of bilingualism (Bialystok, 1988, 2001; Cummins, 1977; Gutiérrez-Clellan, 1999; Perozzi, 1985; Perozzi \& Chávez Sánchez, 1992).

Kiernan and Swisher (1990) conducted a study supporting the Thresholds Theory in which the researchers taught children an imaginary language. The participants were Navajo and Spanish-speaking children who were learning English as their L2. The team taught the participants new vocabulary words in two conditions. In the first condition, children were taught novel words using their L1, and subsequently were taught the words in L2. The second condition bypassed teaching the children the new words in $\mathrm{Ll}$ and solely focused on teaching in L2. The results of the study demonstrated that the children reached criterion more quickly when being instructed in L1 prior to L2. These results occurred regardless of the participants' L1.

In addition, Bialystok (1988) completed two studies with first grade students that support the Thresholds Theory. The investigator hypothesized that fully bilingual children (children in the later stages of language learning) would perform better on metalinguistic tasks than partially bilingual children (those in the earlier stages of language learning) and monolingual students. The participants in the first study included 
20 partially bilingual French-English speaking students, 17 fully bilingual French-English speaking children, and 20 monolingual English-speaking students. The tasks included testing the children's ability to accept different names for common objects, determine which stimuli were words, define what a word is, and detect syntactic errors. The fully bilingual children's scores were the highest, and the monolingual children's scores were the lowest.

The participants in the second study included children who were taught in English, yet who communicated in Italian at home with varying proficiencies. The children were tested utilizing the aforementioned tasks, except the task to test the children's ability to accept a different name for a common object was changed. Additionally, the task to determine the grammaticality of a sentence was presented orally as opposed to written form. The Peabody Picture Vocabulary Test (PPVT) was administered in English (EPPVT) and was translated into Italian (IPPVT) to determine the students' proficiency in both English and Italian. The test results determined that all of the children were more proficient in English (Bialystok, 2001; Dunn, Dunn, Robertson, \& Eisenberg, 1959).

The children scored similarly when determining whether a sentence was stated in a grammatical fashion. The students' levels of bilingualism did not significantly alter their performance on this task. Children who achieved the best results on the EPPVT scored highest when asked to define what a word is. The authors attribute this finding to the group's advanced ability in analyzing linguistic information. However, overall, the 
children who were judged to be more bilingual achieved higher scores than the children who possessed less proficiency in both languages (Bialystok, 1988).

Developmental Interdependence Hypothesis: Optimal Learning of L2 Concept Knowledge

Sequela to the Thresholds Theory is Cummins' Developmental Interdependence hypothesis which states that children must posses sufficient proficiency in their first language in order to support optimal L2 learning (Cummins, 1979). Children who are more advanced in their L1 can acquire L2 more rapidly. Consequently, when children's L1 proficiency is low, their aptitude to acquire L2 diminishes.

Huguet et al. (2000) conducted a study that supports the Developmental Interdependence hypothesis. The research team investigated the language use of Spanish and Catalán in the Spanish provinces of Aragón and Catalonia. Subsequent to Franco's dictatorial regime and pressure to solely utilize Spanish, the province of Catalonia deemed Catalán an official indigenous language of the province and in 1983 instated the Language Planning Act (Llei de Normalizació Lingüistica). Both Spanish and Catalán are the languages of instruction in the schools. However, Aragón did not institute such a policy, and an optional Catalán language program exists.

The participants included 389 male and female students from Aragón. Two hundred students were from eastern Aragón, the bilingual sector of the province, and 141 of those students formally learned Catalán in an optional Catalán language program. The remaining 59 students did not attend the Catalán language classes. The students spoke 
Catalán as their L1 and Spanish as their L2. Eighty-nine participants lived in the monolingual Spanish-speaking sector of Aragón.

The eastern Aragonese language proficiencies in Catalán were compared to Catalonian students' Catalán proficiency who spoke the language as their L1. The investigators determined that the Catalonian students had higher oral and written language proficiencies in both Catalán and Spanish. The residents of Aragón who informally learned Catalán as their L1 in the home possessed lower proficiencies in both L1 and L2 (Spanish) than their Catalonian counterparts. The authors emphasized that although the eastern Aragonese students informally learned Catalán in the home, consistent formal language learning is important to most effectively learn L2. The Catalonian students formally learned L1 in the province's schools, and therefore were better able to transfer their L1 linguistic knowledge to L2. These results support the Developmental Interdependence hypothesis because the Catalonian students possessed a stronger L1 (Catalán) base and consequently obtained a higher proficiency in L2 (Spanish) (Huguet et al., 2000).

Perozzi (1985) and Perozzi and Chávez Sánchez (1992) conducted studies regarding the transference of knowledge from L1 to L2. Specifically, the results of a single-subject study by Perozzi (1985) determined that a child's learning of L2 is aided by learning the corresponding concept labels in his/her L1. The children who first learned vocabulary words in L1, learned those words in L2 at a quicker rate than if they learned words in L2 and subsequently in L1. However, this study only contained three 
English speaking and three Spanish speaking children, and consequently a larger $\mathrm{N}$ should be used in order to better prove the results.

Futhermore, Perozzi and Chávez Sánchez (1992) conducted a study to determine the effects of L1 instruction on the comprehension skills of bilingual Spanish-English speaking first grade students with language delays in L2. Group A first received instruction in Spanish. After the group achieved comprehension of the prepositions and pronouns being taught, they were trained to say the same words in English. Group B solely received instruction in Spanish. The researchers determined that providing the students with L1 instruction first and then teaching the students in L2 positively influenced the children's receptive language acquisition.

Factors Influencing Successful Bilingual Language Acquisition

Individual, familial, and societal characteristics influence the probability of a child becoming bilingual. The fewer years a child has lived in the United States, the greater chance s/he will possess proficiency in more than one language. Children who are females and being of Latino origin increase the probability of being bilingual. Additionally, a person's motivation and natural ability to learn languages influence one's ability to develop bilingual language skills (Bialystok, 2001; Hammer, Miccio, \& Rodríguez, 2004; Langdon, 2008).

Children raised in bilingual environments from a higher socioeconomic status (SES) tend to preserve their bilingualism in comparison to children coming from a lower SES background (Hammer et al., 2004). In 2005, 28\% of Hispanic children lived in poverty in comparison to $16 \%$ of all children living in the United States (Federal 
Interagency Forum on Child and Family Statistics). Children from lower SES backgrounds may not have the opportunity to grow up in literacy-rich environments. Their parents may also have more stress associated with insufficient finances necessary to meet daily needs (Hammer et al., 2004; Langdon, 2008; Oller \& Eilers, 2002). Therefore, children from low SES backgrounds may require more time to develop competency in both L1 and L2.

In addition, children living in a home with parents who speak a language other than English are more likely to become bilingual (Hammer et al., 2004). Parents who speak their native language with their children are sharing the culture connected with that language. For example, Cuban parents living in the United States who speak Spanish with their children teach their children "... ways of perceiving and organizing experience, ways of anticipating the world, forms of social relationship, rules and conventions about behavior, and moral values and ideals..." affiliated with being Cuban (Baker, 2006, p. 17).

In regard to societal factors, children living in an "additive" (Baker, 2006, p. 4) as opposed to a "subtractive" (p. 4) society tend to become bilingual. An additive society embraces and values language diversity and encourages children to become multilingual. Schools implement bilingual education programs for the purpose of building children's language repertoires in numerous languages. Naturally, more children choose and learn to speak two or more languages. In an additive environment, a second language adds to a child's home language and culture. An example of where additive bilingualism occurs is 
in Catalonia, Spain where most children learn Catalán, Castellano, and English (Huguet et al., 2000).

In subtractive bilingualism, however, the acquisition of a second language replaces the first language and the culture associated with the home language (Baker, 2006, 2007; Patterson \& Pearson, 2004). Subtractive bilingualism is common in the United States; specifically in relation to children who speak Spanish as their home language, and who speak English as their L2. The U.S. is an example of a subtractive environment in regard to multilingualism in that children are encouraged to quickly learn and speak only English in the majority of schools and communities. Additionally, in the United States, in some communities, individuals who speak certain languages other than English (such as Spanish) are perceived as less educated, lazy, or of a lower socioeconomic status (García, 2002). This is in comparison to much of Europe where multilingualism is encouraged.

Why Assess in Two Languages?

BICS requires approximately 1 to 3 years to develop, and CALP requires 5 to 7 years to grow. Therefore, when children learning a second language are only tested in their L2, the knowledge they possess in L1 may not be identified. Test scores may seem below average in English, because their linguistic knowledge in L1 has not been evaluated. Thus, testing bilingual students in one language fails to assess the students' actual language ability (Gutiérrez-Clellan \& Peña, 2001).

Additionally, speech-language pathologists who do not conduct assessments in two languages for bilingual students may be violating federal and state mandates. Public 
Law 94-192 provides bilingual children with a right to evaluations that are culturally appropriate, including testing in the child's first language. Children may be mislabeled as language disordered when they are actually demonstrating language differences (Baker, 2007; Papoutsis Kritikos, 2003). Furthermore, when children are assessed in both L1 and L2, the evaluation of the children's language performance will be more precise, and if a language delay/disorder is identified, suitable goals could be formulated and implemented. As a result, these children would receive the appropriate services earlier and could achieve their academic potential.

In summary, one must consider the importance of a solid language base in L1 and its relevance to the efficient promotion of $\mathrm{L} 2$ growth. The current research was conducted to determine the detected levels of concept development in English and Spanish that correlates with children who communicate in Spanish at home with at least $30 \%$ frequency. This will occur by testing basic concept knowledge in the participants' $\mathrm{L} 1$ and L2. 


\section{Chapter 3}

Methodology

\section{Background}

With the implementation of Proposition 227 in 1998, English-only instruction in California public schools became the norm. English Learners are provided with 1 year of English immersion classes before entering mainstream classrooms. Students may not be tested in their first and second languages when educators are determining their concept knowledge. According to research completed regarding second language acquisition, under ideal conditions, Cognitive Academic Language Proficiency, (CALP), the language necessary to perform in an academic setting, requires between 5 to 7 years to develop. Therefore, currently, ELs are not being provided with the opportunity to demonstrate their concept knowledge if only tested in L2. This is especially evident at the preschool level, when students come from environments where only their L1 is spoken (Spanish in this case), and attend classes where instruction is in English only. The No Child Left Behind (NCLB) Act requires that English Learners (ELs) are provided with the appropriate academic supports to learn English and succeed academically. The practices of Proposition 227 contradict the goals of NCLB in regard to ELs and bilingualism research.

The purpose of this study was to clarify the detected basic concept knowledge of typically developing preschool students who speak Spanish as their L1, but are students in preschools where English is the instructional language. This was accomplished by testing the students using the Wiig Assessment of Basic Concepts (WABC) in English and 
Spanish. The two versions of the WABC were utilized to compare bilingual preschool children's detected concept knowledge in the two languages (Wiig \& Langdon, 2006; Wiig, 2004). Permission to conduct this research project was approved by the Institutional Review Board of San José State University.

The characteristics of the study's participants, the tests used to examine the students' basic concept knowledge and the process of selecting participants and collecting the data are described below.

\section{Participants}

Twenty-two typically developing EL children between the ages of 4 and 5 years old were tested using the English and Spanish versions of the WABC to assess their comprehension and expression of various basic concepts. Children who communicated in Spanish with a minimum of $30 \%$ frequency in the home were selected to participate. Twenty-two parents, ages 25 to 40 years old, participated. Two classrooms of preschool students were selected.

The students were recruited from preschool programs conducted in two districts: Alum Rock and Sunnyvale School districts which are part of the Santa Clara County Public School system. The participants were typically developing and healthy (no evidence of frequent ear infections, surgeries, or speech, language and/or cognitive disorders) as indicated by parental and teacher reports. Parents received questionnaires to document their child's home language background and the hours that family members and the child spent communicating in Spanish and English every day (See Appendix A for Parent Questionnaire, p. 69). Healthy, typically developing children who 
communicated in Spanish with a minimum of $30 \%$ frequency were selected. Teachers were asked questions regarding the children who had the appropriate home language background and Spanish skills to further determine the students' eligibility for the study (See Appendix B for Teacher Questionnaire, p. 74).

All participants were ELs whose teachers may not have had accurate records of their basic concept knowledge because the subjects had not been tested using culturally sensitive materials in their primary and secondary languages.

Instruments

The Wiig Assessment of Basic Concepts (WABC) English and Spanish versions (Level 1) are intended for children ages 2.6 to 5.11. The WABC determines a child's receptive and expressive language abilities related to basic concepts that describe shape, form, color, quantity, location, and emotion. Basic concept development is examined by presenting concepts in pairs, showing the concepts in a storybook format, and setting each concept in a picture scene (Wiig Assessment of Basic Concepts-Spanish: Examiner's Manual, 2006; Wiig Assessment of Basic Concepts: Examiner's Manual, 2004).

The WABC first examines a child's receptive language regarding a specific concept. If the child correctly answers the receptive language question, the test examines the child's expressive language in relation to the target concept. For example, the child is asked, "Which bear is big?" If the child points to the big bear (a correct receptive language response), the examiner says, "You showed me big. This bear (pointing to the small bear) is..." If the child answers "small" s/he correctly answered the expressive 
language question and receives two points. The student can also answer "tiny" which is an acceptable response, yet does not carry as high of a point value of one point.

\section{Procedures}

Seventy-five questionnaires were distributed to parents at federal preschool sites where the primary language of instruction is English. From the 75 questionnaires, the examiner determined which children's families use Spanish to communicate in the home at least $30 \%$ of the time. Only 22 students were included in the study; some children were excluded because they were previously identified as having a language difficulty or their parents did not consent to their participation. The teachers of the children who qualified for the study were given questionnaires to verify that the potential subjects were typically developing; specifically, speech and language delays/disorders in addition to frequent ear infections had not been identified.

Each subject completed the WABC in English and Spanish. The tests in English and Spanish were administered to each subject on different days. In the Alum Rock site, the students took the test in English first, and then in Spanish. At the Sunnyvale site, the students took the test in Spanish first and subsequently in English. For example, Subject 1 at the Alum Rock school began by taking the test in Spanish and subsequently in English. Subject 1 at the Sunnyvale school began by taking the test in English and then in Spanish.

The parent and teacher questionnaires were completed in April 2007. The children were tested in April and May 2007. The subjects were tested by the investigator in two different preschool sites in a quiet location in the children's classroom. 


\section{Confidentiality}

To ensure confidentiality, each subject's performance was assigned a number to identify each subject's results on the WABC in English and Spanish and each student's parent and teacher questionnaires. For example, Subject 1's responses were recorded as S1-S (Spanish) and S1-E (English). Subject 2's results were recorded as S2-E and S2-S. The names on the parent and teacher questionnaires were converted to initials. 
Chapter IV

Results and Discussion

\section{Background}

Proposition 227 mandates that after attending only one year of classroom instruction in Spanish, EL students must transition to "English-only" classes. Unfortunately, in California public schools, this practice begins at the preschool level and continues through high school. It is not unusual that EL students enrolled in the mainstream classroom environment are only tested in their second language (L2). Consequently, ELs may not be provided with the opportunity to demonstrate their concept knowledge in both L1 and L2 and may be misidentified as having a language delay and/or disorder.

Educators who are inexperienced in the area of bilingual language acquisition often fail to consider Cummins' (1981) dichotomy between Basic Interpersonal Communication (BICS) which may take between 1 to 3 years to develop, and Cognitive Academic Language Processing (CALP) which may take 5 to 7 years to develop for an EL. Consequently, students could be assessed in English only and without consideration of their performance in L1 (in this case Spanish). This occurs because some educators assume that if students have attended a program in which instruction has been in English, then they should be ready to perform at expected standards in English at any grade level.

The purpose of this study was to describe the basic concept knowledge of bilingual preschool children who speak Spanish at home with at least 30\% frequency. 
Students between the ages of 4 and 5 were tested using the Wiig Assessment of Basic Concepts (WABC) Spanish and English versions.

\section{Data Analysis}

The answers to the following research questions were addressed.

1- Is there a difference between EL children's detected concept knowledge in Spanish in comparison to English when the children communicate in Spanish with family members, relatives and neighbors with at least $30 \%$ frequency?

2- What are the concepts understood and expressed in both Spanish and English, or in Spanish only by students who performed in the average range on the WABC Spanish version? In addition, the concepts identified by the WABC that this group of students comprehended yet did not express in English will be reported.

3- What are the concepts understood and expressed in both English and Spanish, or in English only by students who performed in the average range on the WABC English version? Additionally, the concepts identified by the WABC as comprehended but not expressed in Spanish will be reported.

4- Which concepts were not comprehended or expressed by students performing in the average range on the WABC Spanish version? The same analysis will be conducted for students who performed in the average range on the WABC English version.

5- Finally, which concepts were not understood or expressed by the lowest performing group on both versions of the WABC?

Answers to these questions can provide guidance regarding assessment and pedagogical implications. The study's participants have spoken Spanish for at least 4 
years in the home and have communicated in English for 1 to 2 years at school. Therefore, in order to accurately analyze the children's basic concept acquisition, the basic concept knowledge background of the bilingual preschool students must be assessed in both L1 and L2. Thus, one can obtain a more "objective" view of the children's basic concept acquisition. Second, the student's detected concept knowledge in L1 and L2 must be analyzed to reveal the specific concept labels that these students understand and/or express in each language. This information will serve as a guide for parents' and teachers' collaborative efforts to teach those concepts not yet acquired. Even though 75 requests were sent to parents of EL Spanish-English speaking students to request their children's participation in the study, only 24 were returned. Furthermore, only 22 or $28 \%$ of the total number of requests were appropriate for data analysis.

1- Is there a difference between the EL children's detected concept knowledge in Spanish in comparison to English when the children communicate in Spanish with family members, relatives and neighbors with at least $30 \%$ frequency?

Two analyses were conducted to answer this question. First, the number of children who scored in the average range on the Spanish and English versions of the test was reported. The average range included the number of children who scored within one standard deviation above and below the mean on each version of the WABC. Results are reported in Table 4-1. Second, the number of children who scored at least $50 \%$ correct and $80 \%$ correct on the receptive and expressive sections of the test in each language is documented. These results are reported in Table 4-2. 
Table 4-1

Number of Children Performing in the Average Range

\begin{tabular}{ccc} 
WABC Spanish & WABC English & WABC English/Spanish \\
$13 / 22$ & $6 / 22$ & $5 / 22$ \\
\hline
\end{tabular}

Overall, more children performed better in Spanish (13/22) or 59\% than in English $(6 / 22)$ or $27 \%$. Only five or $23 \%$ of the children performed equally well and within the average range in both languages. The average range was divided into low average, mid average, and high average sectors. Out of the 13 students who performed in the average range in Spanish, nine students performed in the mid or high average sectors. Of the six students performing in the average range in English, only two students performed in the mid average or high average sectors.

It may be that those children who performed better in Spanish did so because Spanish was the children's main language of communication until they enrolled in the preschool program. These results demonstrate the importance of testing students in their first language, L1. If these students were only tested in their L2 (English), one might incorrectly conclude that some of the children were deficient in comprehending and/or expressing particular basic concepts. Those children who performed equally well in both languages may have had a stronger base in their L1 (Spanish) at home, which could have aided them in acquiring the English label for basic concepts with greater ease. 
Scores of only two children were in the mid average or high average sectors on the English version of the WABC. This may indicate that these children chose to focus more on building their English language skills. According to the parent questionnaire, one of the children who performed better at this level communicates with both his mother and father solely in Spanish; he does not communicate in English at home. The other student who performed at this level on the English version of the test communicates with her mother equally in Spanish and English. This child communicates with her father solely in Spanish. The first child may have a strong base in Spanish which has facilitated his acquisition of English. The second child may prefer to speak in English since her home communication background reports that her mother communicates with her in both Spanish and English.

Table 4-2 lists the number of children who scored at least $50 \%$ or $80 \%$ correct on the WABC Spanish and English receptive and expressive sections.

Table 4-2

Number of Children Answering With at Least $50 \%$ or $80 \%$ Accuracy

\begin{tabular}{ccccc}
\hline & \multicolumn{2}{c}{ WABC Spanish } & & \multicolumn{2}{c}{ WABC English } \\
$\%$ Accuracy & Receptive & Expressive & Receptive & Expressive \\
$50 \%$ & 22 & 17 & 21 & 11 \\
$80 \%$ & 17 & 0 & 9 & 0 \\
\hline
\end{tabular}

The number of children who responded with at least $50 \%$ accuracy in response to the Spanish and English basic concept questions was greater than the 80\% accuracy data for both the receptive and expressive sections of the tests. The numbers were similar 
across languages for the $50 \%$ level in the receptive section of the WABC. That is, there were 22 children who answered at least $50 \%$ of the receptive questions in Spanish, and 21 in English. For the expressive section, there were 17 children who responded with $50 \%$ success in Spanish and only 11 in English.

There was a difference in the number of children who responded correctly at the $80 \%$ accuracy level in both languages and areas considered. Nearly double the number of participants scored at least $80 \%$ correct on the receptive section of the WABC in Spanish (17) in comparison to the corresponding section in the English version (9). It was significant to note that no student answered the expressive section with $80 \%$ success in either Spanish or English.

Overall, these results indicate that children were able to respond to questions more accurately in Spanish as compared to English because they were in the process of acquiring English. However, all children had more challenges on the expressive section of the test in both languages.

Several factors may have contributed to the aforementioned results. The receptive section may have been easier than the expressive section because it required children to point to a given picture. Additionally, the developers of the WABC created the test so that the receptive language question is the basic concept usually acquired first by students. It is possible that the children may have been apprehensive to answer the examiner in Spanish in comparison to English because they were in a school where English was the primary language of communication both informally and formally. The reason very few children responded to the expressive section of the WABC in English is 
most likely due to the fact that they did not have the opportunity to sufficiently acquire the language to respond verbally. Since the students were in the process of learning a second language, the $80 \%$ correct response level for the expressive items in English could not be attained.

Naturally, home language background needs to be considered in interpreting these test results. The participants had been communicating in Spanish for at least 4 years, prior to entering school where English was the primary language of interaction. Furthermore, they had attended the program for only 1 to 2 years.

These results also indicate the importance of testing children in both their first and second acquired languages. Educators and parents should realize the frequently occurring gap between detected knowledge on standardized tests and EL children's actual knowledge. The participants in this study demonstrated this occurrence on a small scale. 2- What are the concepts understood and expressed in both Spanish and English, or in Spanish only by students who performed in the average range on the WABC Spanish version? In addition, the concepts identified by the WABC that this group of students comprehended yet did not express in English will be reported.

The purpose of this section was to provide a guideline to identify the concepts comprehended, expressed, or not yet acquired by at least $80 \%$ of the children who scored in the average range on the Spanish version of the WABC. What follows are the types of concepts and corresponding labels in L1 and L2 comprehended and expressed by students performing in the average range on the WABC Spanish version. Additionally, the concepts identified by the WABC as comprehended but not expressed in English by this 
group will be reported. A more complete list of concepts and labels in L1 and L2 that were comprehended and expressed by the students can be found in Appendix C (see p. 76).

Table 4-3 lists the concepts comprehended and expressed in both Spanish and English by at least $80 \%$ of students whose total scores were in the average range on the WABC Spanish version.

Table 4-3

Concepts and Categories Comprehended/Expressed in Spanish and English by at least 80\% of Average Scoring Students on the WABC (Spanish)

Concept

Spanish

El más chiquito/pequeño*

El más grande*

El más largo*

La más alta*

Afuera/adentro

Abajo/arriba/encima

Verde/amarillo

Cerrada/abierta
Smallest

Biggest

Longest

Tallest

Outside/inside/in

Down/up

Green/yellow

Closed/open
Volume

\section{Category}

Volume

Volume

Volume

Location

Direction

Color

Condition

* Concept is only assessed in the receptive section of each WABC language version.

The participants whose scores were in the average range on the WABC Spanish version comprehended and expressed the concept labels in Spanish and English for the 
same 8 concepts out of 29 total concepts tested in Spanish, and 30 total concepts tested in English. When children understood and expressed a basic concept in both Spanish and English (Table 4-3), they may have acquired the concept in one of the languages and subsequently learned the label for that concept in the other language. The concepts in Table 4-3 relate to Volume, Location, Direction, Color, and Condition. The concepts in these categories probably are visible in the children's daily lives at home and in school, encountered with greater frequency in both environments, and therefore, were acquired with greater ease than other concepts.

Table 4-4 includes a list of concepts comprehended and expressed in Spanish, but only comprehended in English by at least $80 \%$ of the students whose total scores were in the average range on the Spanish version of the WABC.

Table 4-4

Concepts and Categories Comprehended/Expressed in Spanish, but Only Comprehended in English by at least $80 \%$ of Average Scoring Students on the WABC (Spanish)

\section{$\underline{\text { Concept }}$}

\section{$\underline{\text { Category }}$}

Spanish

English

\begin{tabular}{ccc}
\hline Mal/bien/bueno/rico & Bad/good & Evaluation \\
Triste/contento/feliz/alegre & Sad/happy/glad & Emotion \\
Fea/bonitas/bellas/lindas,etc. & Ugly/pretty/beautiful & Evaluation \\
Caliente/fria & Hot/Cold & Condition \\
Abajo/debajo/arriba & Under/over/above & Location \\
\hline
\end{tabular}


Table 4-4 includes a list of concepts that the students performing in the average range on the Spanish version of the WABC could comprehend and express in Spanish, but could only comprehend in English. These results indicate that, most likely, the students are in the process of learning the labels for these five concepts in English. These students have begun to learn the English labels for the following concept categories: Evaluation, Emotion, Condition, and Location. The concepts listed in Table 4-4 may have been emphasized at home and in school slightly less often than those listed in Table 4-3.

Table 4-5 includes a list of concepts comprehended and expressed in Spanish but not comprehended or expressed in English by at least $80 \%$ of students who scored within the average range on the WABC Spanish version.

Table 4-5

Concepts and Categories Comprehended/Expressed in Spanish, but Not Comprehended/Expressed in English by at least $80 \%$ of Average Scoring Students on the $W A B C$ (Spanish)

\section{$\underline{\text { Concept }}$}

\section{Category}

Spanish

English

\begin{tabular}{ccc} 
Despierto/durmiendo & Awake/asleep/napping & Condition \\
Todo/nada & None/all & Quantity \\
Abajo/arriba/encima & Bottom/top & Location \\
\hline
\end{tabular}

Table 4-5 includes the three concepts comprehended and expressed in Spanish only but not in English by those students who performed in the average range on the 
WABC Spanish version. In this case, the concepts were in the following categories: Condition, Quantity, and Location. The results suggest that the children learned these concepts at home, and may not have had an opportunity to learn them at school. For example, the concept ("awake/asleep") could have been learned in the context of the home where the students sleep and wake up every day. Therefore, the children are more likely to have acquired the label for this concept in Spanish instead of English. It is difficult to explain why the students have yet to acquire the other two concept labels in English.

3- What are the concepts understood and expressed in both English and Spanish, or in English only by students who performed in the average range on the WABC English version? Additionally, the concepts identified by the WABC as comprehended but not expressed in Spanish will be reported.

The purpose of this section is to provide a guideline to identify the concepts comprehended, expressed, or not yet acquired by at least $85 \%$ of the children who scored in the average range on the WABC English version. The concepts comprehended and/or expressed were calculated for at least $85 \%$ of students (as opposed to $80 \%$ on the WABC Spanish version) due to the different number of students who scored within the average range on the WABC in English. What follows are the types of concepts and corresponding labels in L1 and L2 comprehended and expressed by students performing in the average range on the WABC English version. Additionally, the concepts identified by the WABC as comprehended but not expressed in Spanish by this group will be 
reported. A more complete list of concepts and labels in L1 and L2 that were comprehended/expressed by the students can be found in Appendix C.

Table 4-6 includes a list of the concepts comprehended and expressed in both English and Spanish by at least $85 \%$ of the students whose total scores were in the average range on the English version of the WABC.

Table 4-6

Concepts and Categories Comprehended/Expressed in English and Spanish by at least 85\% of Average Scoring Students on the WABC (English)

\section{Concept}

English

Smallest*

Biggest*

Longest*

Tallest*

Closed/open

Awake/asleep/napping

Hot/cold

Outside/inside/in

Down/up

Under/over/above

Green/yellow

Spanish

Category

Volume

Volume

Volume

Volume

Condition

Cerrada/abierta

Condition

Despierto/durmiendo

Caliente/fría

Condition

Afuera/adentro

Location

Abajo/arriba/encima

Direction

Abajo/debajo/arriba

Location

Verde/amarillo

Color

\footnotetext{
* Concept is only assessed in the receptive section of each WABC language version.
} 
Students performing in the average range on the WABC in English understood and expressed the same 11 concepts in both Spanish and English. The categories corresponding to the concepts in this group include: Volume, Condition, Quality, Location, Direction, and Color. This group understood and expressed three more concepts in both languages in comparison to the group of students who performed in the average range on the WABC Spanish version. These basic concepts ("closed/open," "awake/asleep/napping," and "cold/hot") were most likely reinforced in English. Since these children may have had a more solid foundation in Spanish, they could have learned the English labels with greater ease.

Table 4-7 lists the concept label comprehended and expressed in English, and only comprehended in Spanish by at least $85 \%$ of students who performed in the average range on the WABC English version.

Table 4-7

Concept and Category Comprehended/Expressed in English, but Only Comprehended in Spanish by at least $85 \%$ of Average Scoring Students on the WABC (English)

Concept

English

$\mathrm{Sad} / \mathrm{happy} / \mathrm{glad}$
Triste/contento/feliz/alegre

\section{Category}

Spanish

\begin{tabular}{lll}
\hline Sad/happy/glad $\quad$ Triste/contento/feliz/alegre & Emotion \\
\hline
\end{tabular}

Only one concept ("sad/happy/glad") was comprehended and expressed in English, yet only comprehended in Spanish. The concept pertains to the emotion category. This result can be attributed to cultural differences. Specifically, parents of 
Hispanic origin may not ask the child to say how he/she feels at home compared to the general Anglo-American culture. Heath (1986) reports that parents of Mexican American background may not ask their children to voice their opinions or emotions.

Table 4-8 lists the concept that was comprehended and expressed in English, but not comprehended/expressed in Spanish by at least $85 \%$ of the students who scored in the average range on the English version of the WABC.

Table 4-8

Concept and Category Comprehended/Expressed in English, but Not Comprehended/Expressed in Spanish by at least 85\% of Average Scoring Students on the $W A B C$ (English)

Concept

English

Square/Round

Cuadrada/redonda

Category

Spanish

\begin{tabular}{lll} 
Square/Round & Cuadrada/redonda & Shape \\
\hline
\end{tabular}

Only one concept ("square/round") was understood and expressed in English, but not in Spanish. This concept was most likely acquired at school where entire lessons center on colors and shapes. Therefore, it is not surprising that the children acquired the label for this concept in English, and may not have had the opportunity to learn the label in Spanish.

4- Which concepts were not comprehended or expressed by students performing in the average range on the WABC Spanish version? The same analysis will be conducted for students who performed in the average range on the WABC English version. 
The purpose of this section was to list the concepts that students have not yet acquired. Consequently, these basic concepts can be overtly taught in school and at home.

Table 4-9 lists the concepts that were not comprehended or expressed in either Spanish or English by at least $80 \%$ students who performed in the average range on the Spanish version of the WABC.

Table 4-9

Concepts and Categories Not Comprehended/Expressed in Either Language by at Least $80 \%$ of Average Scoring Students on the WABC (Spanish)

Concept

Spanish

En el medio*

Separado/juntos

Vacío/lleno/repleto

Cuadrada/redonda
Apart/together

Empty/full/filled up

Square/round
Middle*

Category

$$
\text { English }
$$

Location

Location

Volume

Shape

* Concept is only assessed in the receptive section of each WABC language version.

The results reported in Table 4-9 indicate that at least $80 \%$ of the children who performed in the average range on the Spanish version of the test had not acquired four concept labels in either language. The categories associated with these four concepts include: Location, Volume, Shape. The concepts not acquired in these categories ("middle," "apart/together," "empty/full/filled up," and "square/round") may not appear in the children's environment with the same frequency as the concepts that the children 
have already acquired. This suggests that fewer opportunities may have existed for caregivers and teachers to overtly teach these concepts.

It is possible that the children were not able to understand the preposition "middle" because it requires greater perspective skills; specifically, the ability to process and visualize greater than one dimension. According to Piaget and Inhelder (1956), the ability to perceive multidimensional space emerges during the concrete operational stage of cognitive development when children are 7 to 11 years old. For the same reason, the children may not have responded to the concept ("empty/full/filled up") which denotes volume. This concept requires the understanding of three-dimensional shapes and according to Piaget is expected of children between the ages of 7 and 11 years old. Therefore, the children in this study may not have the cognitive/maturation levels necessary to decipher the two aforementioned concepts.

Table 4-10 lists the concepts not comprehended or expressed by at least $85 \%$ of the students who performed in the average range on the WABC English version.

Table 4-10

Concepts and Categories Not Comprehended/Expressed in Either Language by at least 85\% of Average Scoring Students on the WABC (English)

\section{Concept \\ Category}

\begin{tabular}{lll}
\multicolumn{1}{c}{ English } & Spanish & \\
\hline Middle* $^{*}$ & En el medio & Location \\
Apart/together & Separado/juntos & Location \\
\hline
\end{tabular}

* Concept is only assessed in the receptive section of each WABC language version. 
There were two concepts ("middle" and "apart/together") that at least $85 \%$ of the children who performed in the average range on the WABC English version could not comprehend or express in either Spanish or English. Therefore, these concepts have not yet been acquired.

Overall, fewer concepts had not been acquired by children who performed in the average range on the WABC English version; specifically two instead of four concepts had not been acquired. Interestingly, those students who scored in the average range in Spanish knew the Spanish and English labels for only eight concepts (Table 4-3). The data reported are compared to children scoring in the average range on the WABC English version who knew the Spanish and English labels for 11 concepts (Table 4-6). This suggests that the children who scored in the average range on the English version of the WABC have a stronger basic concept vocabulary base in Spanish as well. They have acquired more labels for basic concepts in both Spanish and English than the other groups analyzed. It is likely that a strong language base in the children's L1 (in this case Spanish) contributed to the student's acquisition of basic concept labels in L2 (English). In regard to concept acquisition, one must also consider the different home communication environments in which the children are living. Each family emphasizes different basic concepts which have an influence on a child's learning of a given range of basic concepts. This may account for the varied performance among the basic concept results between the Spanish and English versions of the test.

5- Finally, which concepts were not understood or expressed by the lowest performing group on both versions of the $W A B C$ ? 
The purpose of this section was to clarify which concepts caregivers and educators should strive to teach students who scored the lowest on the WABC Spanish and English versions. The following concepts and categories were not comprehended/expressed by all of the lowest performing students on both versions of the test. A more complete list of the concepts and concept labels in L1 and L2 that this group comprehended/expressed can be found in Appendix C.

Table 4-11

Concepts \& Categories Not Comprehended/Expressed by 7 Lowest Performing Children on Both Versions of the Test

\section{Concept}

Spanish

En el medio*

Despierto/durmiendo

Cuadrada/redonda

Separado/juntos

Vieja/nueva

Iguales/diferente

Vacío/lleno/repleto

El más largo

La más alta
Middle*

Awake/asleep/napping

Square/round

Apart/together

Old/new

Different/same/alike

Empty/full/filled up

Longest

Tallest

\section{$\underline{\text { Category }}$}

Location

Condition

Shape

Location

Condition

Evaluation

Volume

Volume

Volume

*Concept is only assessed in the receptive section of each WABC language version. 
The lowest scoring students could not comprehend or express nine concepts from the WABC in Spanish or English. It is important to mention that the design of the test instructs the examiner to forego presenting the expressive question if the student fails to answer or answers the receptive item incorrectly. Some students may have scored higher on the expressive section of the tests without the aforementioned guideline.

The concepts the children answered correctly probably have been emphasized in both the home and school environments for the participant sample that was analyzed. Therefore, the students have learned the labels for these basic concepts in both Spanish and English. The receptive and expressive components of the concepts that the seven lowest performing participants answered incorrectly may not have been emphasized in the home or the school settings. Since these students scored lower than other children in the study, it is imperative that parents and teachers are diligent in teaching the concepts that have not yet emerged. Concept labels that are detected as having emerged in one language, yet not in the other should be examined as well (see Appendix C). In this case, parents and teachers can teach the children the labels for those concepts in L2 since the students had already acquired those concept labels in their L1 or vice versa. 


\section{Chapter V}

Summary, Conclusions, and Recommendations

Summary

Currently, numerous English Learners (ELs) are being educated in California's public school system, and Hispanic second language learners have not obtained great levels of academic achievement. Specifically, Hispanics in California are the second largest group to drop out of school. In order to address this issue, the state's present legislation regarding ELs, Proposition 227, requires that children are placed in classrooms where instruction is solely conducted in English after receiving 1 year of instruction in L1. Consequently, numerous children who are learning English as a second language are not necessarily tested in their L1. Given that EL children's acquired knowledge cannot be accurately assessed via testing only in $\mathrm{L} 2$, their true academic strengths and weaknesses are not being identified and possibly are being misidentified. Consequently, without data in both L1 and L2, educators cannot adequately remediate gaps in the EL children's knowledge base as mandated by No Child Left Behind legislation. Research has shown that basic concept knowledge is linked to academic success. Therefore, children who are learning English as a second language in California may not reach their full academic potential as a result of the school system's approach toward EL students.

The purpose of this study was to examine the detected basic concept knowledge of bilingual preschool children who communicate in Spanish at home with at least $30 \%$ frequency by testing the children using the WABC Spanish and English versions. 
Therefore, educators and parents can have a better understanding of the students' concept knowledge, and subsequently focus on teaching those basic concepts not yet acquired. Most of the participants had only been communicating in English for 1 year as a result of entering preschool, and the small remainder had communicated in English for 2 years while attending school. The investigator wished to clarify the difference in concept knowledge between children who performed in the average range on the WABC Spanish and English versions; specifically, the concepts and concept labels understood and/or expressed by students who performed in the average range on each version of the test was studied. Additionally, the study clarified the concepts not yet acquired by students who performed in the average range on the WABC Spanish and English versions, and those students who obtained the lowest performance on both tests.

Proposition 227 is merely one piece of legislation that is indicative of U.S. policy regarding bilingual education that has fluctuated depending on the social and economic climate of the times. Traditionally, legislation has not corresponded with research focusing on bilingualism. Proposition 227 contradicts what research suggests as the optimal manner and time to acquire a second language. Cummins' research suggests that Basic Interpersonal Communication Skills (BICS) requires 1 to 3 years to acquire in L2, and Cognitive Academic Language Proficiency (CALP) requires 5 to 7 years to develop. CALP encompasses academically based learning. Therefore, children who are acquiring L2 and enter an English only classroom have not yet acquired the language proficiency to most effectively learn new material in their second language. 
Furthermore, when examining the study's results, one should consider the manner in which basic concepts are acquired by both monolingual and bilingual individuals. Various theories exist regarding concept development in both groups. Piaget's theory related to concept development suggests that children are cognitively prepared to grasp various types of concept knowledge at different developmental stages. The children in this study are in the preoperational stage of development (ages 2 to 7 ), in which they use words to represent objects with greater ease than younger children. According to other researchers, monolingual individuals may begin to categorize common objects in their environment depending on their specific or variable features. Furthermore, individuals categorize concepts depending on their function and similarities/differences. In addition to an individual's cognitive readiness to acquire a basic concept, basic concept acquisition in bilingual individuals depends upon the frequency or use of a concept in a given language and the frequency of the concept in conversation. Naturally, various cultures place emphasis on different ideas, which consequently affect children's basic concept acquisition.

When examining basic concept knowledge in children who recently began acquiring a second language (i.e. within the past few years), several theories must be taken into consideration. First, Cummins' Common Underlying Proficiency Model (CUP) explains that concept knowledge is stored in a common processing system underlying both $\mathrm{L} 1$ and $\mathrm{L} 2$. The basic concept knowledge that has been acquired by bilingual children is manifested in either L1 or L2 using different phonology and syntax depending on the conversation partner and environment. Additionally, Cummins' 
Thresholds Theory emphasizes the importance of a second language learner possessing a certain level of L1 and L2 knowledge in order to fully grasp academic knowledge in his/her L2, and to obtain the benefits of bilingualism. Furthermore, the Developmental Interdependence hypothesis suggests that individuals need a strong base in L1 in order to most effectively acquire L2 (Cummins, 1977, 1981).

This study examined the basic concept knowledge in children who have acquired Spanish as their L1 and who have subsequently acquired English as their L2 during the past one or two years in school. The participants were selected by the investigator administering 75 parent questionnaires in the Alum Rock and Sunnyvale school districts. Parents filled out questionnaires regarding the children's health and daily language use in L1 and L2. The teachers of students appropriate for the study completed information regarding the children's perceived basic concept knowledge in Spanish and English. Ultimately, 22 typically developing, healthy students from two school districts who communicated in Spanish with at least 30\% frequency in the home were chosen to participate. The investigator administered the WABC in Spanish and English to each child in order to determine the students' detected basic concept knowledge in Spanish and English.

\section{Conclusions}

This study's results indicate the importance of testing students in both L1 and L2 in order to compile accurate data regarding bilingual children's basic concept knowledge. More students performed in the average range on the WABC Spanish version in comparison to the English version. Therefore, although most of the children had been 
attending school in English for 1 year, they still performed better on the Spanish version of the WABC. Children may have responded better to questions in Spanish because Spanish was their native language and they had greater facility in that language. The concepts that children scoring in the average range on the WABC Spanish version comprehended and expressed in both Spanish and English were related to the following categories: Volume, Direction, Location, Color, and Condition. The concepts in these categories may have been emphasized in the children's environment and were more developmentally appropriate for the students to acquire.

The concepts that the children performing in the average range on the WABC Spanish version comprehended and expressed in Spanish, but only comprehended in English were those concepts that the children still had not acquired the label for in English. If the children were only tested in English, the examiner may have incorrectly evaluated the children's basic concept knowledge. Furthermore, the concepts that the children comprehended and expressed in Spanish only were concepts that the children's parents may have emphasized at home, and that the children probably have not yet learned at school.

The children who performed in the average range on the WABC English version comprehended and expressed more concept labels in Spanish and English in comparison to the children who performed in the average range on the WABC Spanish version. This may be due to this group's strong language base in Spanish which allowed them to more quickly acquire the English label for certain basic concepts. There was only one concept ("sad/happy/glad") comprehended and expressed in English, but only comprehended in 
Spanish. This concept was most likely emphasized in school. Some research suggests that one's feelings are not emphasized to the same degree in Mexican-American backgrounds as in Anglo-American culture. This could be one of the reasons why children understood and expressed this concept in English, yet only comprehended the concept in Spanish. Furthermore, there was only one concept ("square/round") which was comprehended and expressed in English, and neither comprehended or expressed in Spanish. This concept was most likely acquired at school, given that shapes are a common lesson topic.

The concepts not comprehended and expressed by the children who performed in the average range on either the WABC Spanish or English versions are concepts that may not have occurred with much frequency in the children's environment. Furthermore, according to Piaget, these concepts may be more easily acquired at a later developmental stage. The concepts the seven lowest performing children on both versions of the WABC did not comprehend nor express may not have been emphasized in their homes suggesting that these children have not had the opportunity to acquire these concepts. In response to learning which concepts the children have and have not acquired, educators and parents can take steps to aid in their children's acquisition of specific basic concepts.

\section{Recommendations}

The results of this research project can provide parents, teachers and caregivers with useful information regarding how to reinforce comprehension and expression of concepts that are fundamental to comprehension and expression of language. This knowledge will enable students to benefit from formal instruction in a classroom setting 
where these concepts are used in different formats such as listening, speaking, and later reading and writing. The concepts that were probed in the WABC in both English and Spanish are of a universal nature. Specifically, no matter what the language, there should be concept labels to denote Color, Shape, Weight, Volume, Distance, Speed, Time, Quantity, Completeness, Location, Direction, Condition, Quality, Sensation, Emotion, and Evaluation.

Additionally, caregivers and educators can teach concept labels that are detected to have emerged in either L1 or L2 in the language in which they have not yet been acquired. In order to teach the label of a concept a child has already acquired in one language, caregivers and teachers can explain that objects have two names: one in Spanish and one in English. Teaching these concepts and concept labels can occur in the form of play and by themes. For example, if a student displays that $\mathrm{s} / \mathrm{he}$ had not yet acquired concepts in the Location and Direction categories, parents and teachers can complete activities demonstrating objects outside and inside, apart and together, above and below, etc. In the home, parents can emphasize that certain household items are above and below, over here and there, etc. Teaching new concepts in a naturalistic environment is usually most effective.

In regard to improving the study, personally interviewing the participants' parents may have improved the completion of the parent questionnaires. Parents may have felt more comfortable completing the questionnaires with the investigator present to answer any concerns regarding the purpose of the study in relation to their children. Additionally, the investigator could have aided parents who had difficulty reading the 
questionnaire to complete the questions. Furthermore, a larger sample size could reap more accurate results. In the future, it would be beneficial to complete this study with students who have been learning a second language for more than 1 year. Specifically, it would be useful to examine the basic concept knowledge of students who have been learning English as their L2 for 5 to 7 years, the same time period Cummins suggested that children acquire Cognitive Academic Language Proficiency in a second language. In this way, researchers can examine the learning of concept labels in L1 and L2 as time progresses and children acquire more language in L2. 


\section{References}

Baca, L.M. \& Cervantes, H.T. (2004). The bilingual special education interface. Upper Saddle River, NJ: Pearson.

Baker, C. (2006). Foundations of bilingual education and bilingualism. ( $4^{\text {th }}$ Edition) Clevedon, UK: Multilingual Matters Ltd.

Baker, C. (2007). A parents' and teachers' guide to bilingualism ( $3^{\text {rd }}$ Edition). Clevedon,UK: Multilingual Matters Ltd.

Baker, K.A., \& de Kanter, A.A. (1983). Federal policy and the effectiveness of bilingual education. In K.A. Baker \& A.A. de Kanter (Eds.), Bilingual education: A reappraisal of federal policy. Lexington, MA: Lexington Books.

Bialystok, E. (2001). Bilingualism in development: Language, literacy, and cognition. New York: Cambridge University Press.

Bialystok, E. (1988). Levels of bilingualism and levels of linguistic awareness. Developmental Psychology, 24, 560-567.

Bracken, B.A. (1998). Bracken Basic Concept Scale-Revised. Examiner's Manual. Harcourt Brace \& Company, San Antonio.

Brisk, M.E. (2006). Bilingual education: From compensatory to quality schooling $\left(2^{\text {nd }}\right.$ ed.). Mahwah, NJ: Lawrence Erlbaum Associates.

California Department of Education: Reclassification of English Learners to Fluent English Proficient. Retrieved July 21, 2007 from http:/www.cde.ca.gov/sp/el/rd/

Crawford, J. (2000). At war with diversity: U.S. Language policy in an age of anxiety. Clevedon: Multilingual Matters.

Cummins, J. (1977). Cognitive factors associated with the attainment of intermediate levels of bilingual skills. Modern Language Journal, 61, 3-12.

Cummins, J. (1979). Interdependence and the educational development of bilingual children. Review of Educational Research, 49, 222-251.

Cummins, J. (1980). The construct of language proficiency in bilingual education. In J.E. ALATIS (ed.) Georgetown University Round Table on Languages and Linguistics 1980. Washington, DC: Georgetown University Press. 
Cummins, J. (1981). Bilingualism and minority language children. Ontario: Ontario Institute for Studies in Education.

Cummins, J. (1984). Bilingualism and special education: Issues in assessment and pedagogy. Clevedon, UK: Multilingual Matters, Ltd.

Dunn, L.M., Dunn, L.M., Robertson, G.J. \& Eisenberg, J.L. (1959). Peabody Picture Vocabulary Test. American Guidance Service.

Ellis, L., Schlaudecker, C., Regimbal, C. (1995). Effectiveness of a collaborative consultation approach to basic concept instruction with kindergarten children. Language, Speech, and Hearing Services in Schools, 26, 69-74.

Escamilla, K. (1994). Goals 2000 and language-minority students: Skeptical optimism. NABE News, 17(7), 3.

Federal Interagency Forum on Child and Family Statistics. Retrieved July 14, 2007 from file://C:IDOCUME 1 1Owner|LOCALS 1\TemplOKSC44F2.htm

Garcia, E. (2002). Bilingualism and schooling in the United States. International Journal of the sociology of language, 155/156, 1-123.

Genesee (2001). Bilingual first language acquisition: Exploring the limits of the language faculty. Annual Review of Applied Linguistics, 21, 153-168.

Gleason (2001). The Development of Language. Needham Heights, MA: Allyn and Bacon.

Goldstein, B. (2004). Bilingual Language development and disorders in Spanish-English speakers. Baltimore, MA: Paul H. Brookes Publishing Co.

Gutiérrez-Clellen, V.F. (1999). Language choice in intervention with bilingual children. American Journal of Speech-Language Pathology, 8, 291-302.

Gutiérrez-Clellan, V.F. \& Peña, E. (2001). Dynamic assessment of diverse children: A tutorial. Language, Speech, and Hearing Services in Schools, 32, 212-224.

Hammer, C.S., Miccio, A.W., \& Rodriguez, B.L. (2004). Bilingual language acquisition and the child socialization process. In B.A. Goldstein (Ed.) Bilingual language development \& disorders in Spanish-English speakers (pp. 21-50). Baltimore, MA: Paul H. Brookes Publishing Co. 
Huguet, A., Vila, I., \& Llurda, E. (2000). Minority language education in unbalanced bilingual situations: A case for the linguistic interdependence hypothesis. Journal of Psycholinguistic Research, 29, 313-333.

Kiernan, B. \& Swisher, L. (1990). The initial learning of novel English words: Two single-subject experiments with minority language children. Journal of Speech and Hearing Research, 33, 707-716.

Kohnert (2004). Processing skills in early sequential bilinguals. In B.A. Goldstein (Ed.) Bilingual language development \& disorders in Spanish-English speakers (pp. 53-76). Baltimore, MA: Paul H. Brookes Publishing Co.

Langdon, H. W. (2008). Assessment and intervention of communicative disorders in culturally and linguistically diverse populations. Clifton, NY: Thomson-Delmar Learning.

Linguistic Minority Research Institute. (2003). Institutional services for California English learners, 2004. Retrieved April 2, 2004, from http://www.lmri.ucsb.edu/resdiss/2/elfacts.htm

Nelson, K. \& Nelson, A.P. (1990). Category production in response to script and category cues by kindergarten and second-grade children. Journal of Applied Developmental Psychology, 11, 431-446.

No Child Left Behind: Building on results: A Blueprint for strengthening the No Child Left Behind Act. Retrieved July 19, 2007 from http://www.ed.gov/policy/elsec/leg/nclb/buildingonresults.pdf

Oller, D. \& Eilers, R.E. (2002). Language and literacy in bilingual children Clevedon, England: Multilingual Matters.

Padrón, Y.N., Waxman, H.C., \& Rivera, H.H. (2002). Educating Hispanic students: Obstacles and avenues to improved academic achievement. (Educational Practice Report 8). Washington, DC: Office of Educational Research and Improvement.

Papoutsis Kritikos, E. (2003). Speech-language pathologists' beliefs about language assessment of bilingual/bicultural individuals, American Journal of SpeechLanguage Pathology, 12, 73-91.

Patterson, J.L. \& Pearson, B.Z. (2004). Bilingual lexical development: Influences, contexts, and processes. In B.A. Goldstein (Ed.) Bilingual language development $\&$ disorders in Spanish-English speakers (pp. 77-104). Baltimore, MA: Paul H. Brookes Publishing Co. 
Pearson, W. \& McAndrews, T. (1982). Concept acquisition and school progress: An examination of the Boehm test of basic concepts. Psychological Reports, 50, 783786.

Peña, E. (2001). Assessment of semantic knowledge: Use of feedback and clinical interviewing. Seminars in Speech and Language, 22, 51-63.

Peña, E.D., Bedore, L.M., \& Rapazzo, C. (2003). Comparison of Spanish, English, and bilingual children's performance across semantic tasks. Language, Speech, and Hearing Services in Schools, 34, 5-16.

Peña, E.D., Bedore, L.M., \& Zlatic-Giunta, R. (2002). Category-generation performance of bilingual children: The influence of condition, category, and language. Journal of Speech, Language, and Hearing Research, 45, 938-947.

Perozzi, J.A. (1985). A pilot study of language facilitation for bilingual, languagehandicapped children: Theoretical and intervention implications. Journal of Speech and Hearing Disorders, 50, 403-406.

Perozzi, J.A. \& Chávez Sánchez, M.A. (1992). The effect of instruction in L1 on receptive acquisition of L 2 for bilingual children with language delay. Language, Speech, and Hearing Services in Schools, 23, 348-352.

Piaget, J. \& Inhelder, B. (1956). The child's conception of space. London, UK: Routledge.

Proposition 227. [Text of the California law banning native language instruction]. Retrieved July 21, 2007 from http://primary98.s.ca.gov/VoterGuide/Propositions/227text.htm

Seifert, H. \& Schwarz, I. (1991). Treatment effectiveness of large group basic concept instruction with head start students. Language, Speech, and Hearing Services in Schools, 22, 60-64.

Statewide Dropout Reports. Retrieved June 24, 2007 from http://dq.cde.ca.gov/dataquest/DropEthState.asp?Level=State\&TheYear=200506\&cChoice $=$ DropEth $1 \& \mathrm{p}=2$

Statewide English Learners by Language and Grade. Retrieved June 22, 2007 from http://dq.cde.ca.gove/dataquest/LEPbyLangd1 .asp?cChoice=LepbyLang1 \&cYear $=2005-06 \&$ cLevel $=$ State $\&$ cTopic $=$ LC\&myTime 
Thomas, W., \& Collier, V. (1997). School effectiveness for language minority students [NCBE Resource Collection Series No. 9]. Washington, DC: National Clearinghouse for Bilingual Education. Retrieved 8/14/07 from http://www.ncela.gwu.edu/pubs/resource/effectiveness/thomas-collier97.pdf

Thomas, W., \& Collier, V (2002). A national study of school effectiveness for language minority students' long-term academic achievement. Santa Cruz. CA: Center for Research on Education, Diversity, and Excellence. Retrieved 8/14/07 from http://crede.berkeley.edu/research/llaa/1.1_final.html

United Nations Educational, Scientific and Cultural Organization (UNESCO) (1953). The use of vernacular languages in education. Paris: Author.

U.S. Code Title 20, 1968. Retrieved July 18, 2007 from http://www4.law.cornell.edu/uscode/html/uscode20/usc_sup_01_20.html

Wiig, E.H., \& Langdon, H.W. (2006) Wiig Assessment of Basic Concepts-Spanish. Greenville, SC: Super Duper Publications.

Wiig, E.H. (2004) Wiig Assessment of Basic Concepts. Greenville, SC: Super Duper Publications. 
Appendix A 


\section{Parent Questionnaire}

Please fill out the following information as accurately as possible.

Student's Name:

School Name:

Teacher's Name:

1. How many years has your child been in the preschool program?

12 (Circle one)

2. Has your child had frequent ear infections, surgeries, or other serious medical conditions?

No

Yes

Please Explain

3. Has your child been diagnosed with a speech or language delay/disorder? No

Yes

Please Explain

4. Please fill out the following table with the number (\#) of hours that each person communicates in each language daily with your son/daughter.

\begin{tabular}{|c|l|l|}
\hline $\begin{array}{c}\text { Family living in } \\
\text { the home }\end{array}$ & $\begin{array}{c}\text { Total hours speaking Spanish } \\
\text { daily }\end{array}$ & $\begin{array}{c}\text { Total hours speaking English } \\
\text { daily }\end{array}$ \\
\hline$\underline{\text { Mother }}$ & \# of hours & \# of hours \\
\hline$\underline{\text { Father }}$ & \# of hours & \# of hours \\
\hline
\end{tabular}




\begin{tabular}{|c|c|c|}
\hline $\begin{array}{l}\frac{\text { Other family }}{\text { members living in }} \\
\text { the home } \\
\text { Brother(s) } \\
\text { Sister(s) } \\
\text { Grandma } \\
\text { Grandpa } \\
\text { Uncle/Aunt } \\
\text { Cousin(s) }\end{array}$ & $\begin{array}{l}\text { \# of hours } \\
\text { \# of hours } \\
\text { \# of hours } \\
\text { \# of hours } \\
\text { \# of hours } \\
\text { \# of hours }\end{array}$ & $\begin{array}{l}\text { \# of hours } \\
\text { \# of hours } \\
\text { \# of hours } \\
\text { \# of hours } \\
\text { \# of hours } \\
\text { \# of hours }\end{array}$ \\
\hline $\begin{array}{l}\frac{\text { With people who }}{\text { take care of your }} \\
\frac{\text { child during the day }}{\text { (Ex. neighbor) }}\end{array}$ & & \\
\hline $\begin{array}{l}1 . \\
2 . \\
3 .\end{array}$ & $\begin{array}{l}\text { \# of hours } \\
\text { \# of hours } \\
\text { \# of hours }\end{array}$ & $\begin{array}{l}\text { \# of hours } \\
\text { \# of hours } \\
\text { \# of hours }\end{array}$ \\
\hline
\end{tabular}

5. About how many total hours of television does your child watch every day? Less than one hour 1-2 hours more than 2 hours

a) How much in English?
Less than one hour
1-2 hours
more than 2 hours

b) How much in Spanish?

Less than one hour

$1-2$ hours

more than 2 hours

6. List three of your child's favorite T.V. programs /videos.

1. 2. 3.

7. On a scale from $1-5$, how would you rate your child's proficiency in the following areas?

\begin{tabular}{|c|c|c|c|c|}
\hline 1 & 2 & 3 & 4 & 5 \\
\hline Minimal & More or less & Intermediate & Advanced & $\begin{array}{c}\text { Very } \\
\text { Advanced }\end{array}$ \\
\hline
\end{tabular}

English: Understanding

Spanish: Understanding
Speaking

Speaking 


\section{Cuestionario para Los Padres}

Por favor llene la siguiente información de la manera más completa posible.

\section{Nombre de su hijo/hija:}

Nombre de escuela:

Nombre de su maestro/a:

1. ¿Cuántos años ha participado su hijo/hija en la preescuela?

12 (Ponga un círculo alrededor de la respuesta correcta.)

2. ¿Su hijo/hija ha tenido infecciones del oído con mucha frecuencia, alguna cirugía, u otra condición seria médica?

No

Sí Explique por favor

3. ¿Alquién ha diagnosticado a su hijo/hija con un desorden/atraso del habla o lenguaje?

No

Sí —xplique por favor

4. Por favor llene la tabla siguiente indicando el número (\#) de horas en que se comunica cada persona en cada uno de los dos idiomas por día con su hijo/a..

\begin{tabular}{|c|l|l|}
\hline Familia que vive en la casa & $\begin{array}{c}\text { Total de horas en que se } \\
\text { comunican en español por } \\
\text { día }\end{array}$ & $\begin{array}{c}\text { Total de horas en que se } \\
\text { comunican en inglés por } \\
\text { día }\end{array}$ \\
\hline Con la mamá & \# de horas_ & \# de horas \\
\hline Con el papá & \# de horas & \# de horas \\
\hline
\end{tabular}




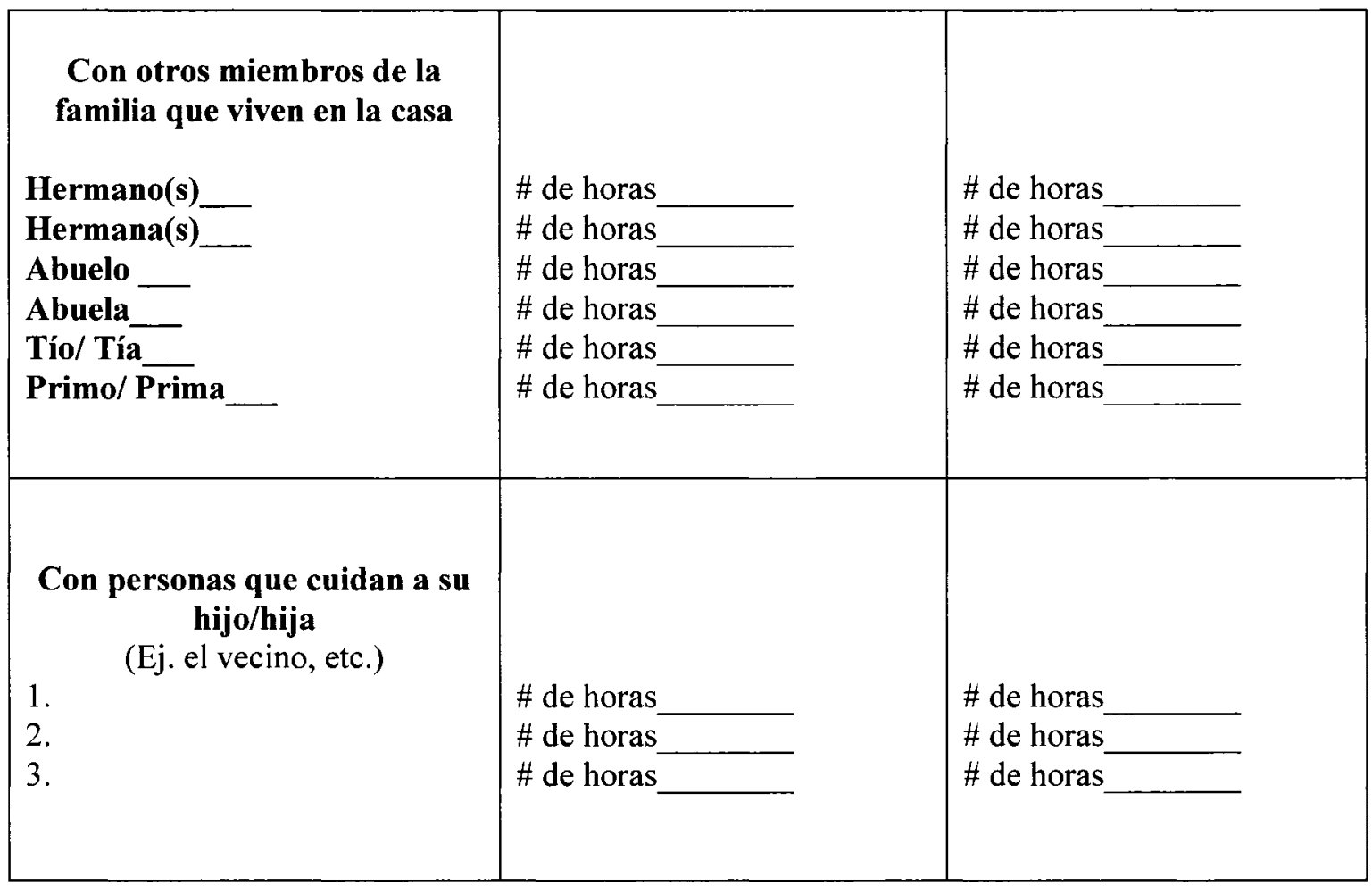

5. ¿Cuántas horas de televisión mira su hijo/hija diario?

Menos de una hora

1-2 horas

más de 2 horas

a) ¿Cuántas horas en español?

Menos de una hora

1-2 horas

más de 2 horas

b) ¿Cuántas horas en inglés?

Menos de una hora

1-2 horas

más de 2 horas

6. ¿Cuáles son 3 de los programas favoritos de su hijo/hija?

1. 2.

3.

7. ¿De una escala de 1-5, cómo describe la habilidad de su hijo/hija en las áreas siguientes?

\begin{tabular}{|c|c|c|c|c|}
\hline 1 & 2 & 3 & 4 & 5 \\
\hline Muy poquito & Algo & Más o menos & Avanzado & Muy avanzado \\
\hline
\end{tabular}

Español: Entendiendo

Hablando

Inglés: Entendiendo Hablando 
Appendix B 


\section{Teacher Questionnaire}

\section{Teacher's Name}

\section{Student's Name}

1. How is the student performing in your class?

Lower than average $\quad$ Average Above average

2. Do you think the student's language experience in English and/or Spanish is affecting his/her performance? If yes, how?

3. On a scale from 1-5 [(1) Below basic (2) Early Intermediate (3) Intermediate (4) Advanced (5) Proficient], how would you rate the student's English proficiency in the following areas: Understanding, Speaking, PreReading, and Pre-Writing?

Understanding Speaking Pre-Reading

Pre-Writing

4. Has this child received extra help for pre-academic subjects? If yes, what kind of support has been provided?

5. Comments: 
Appendix C 


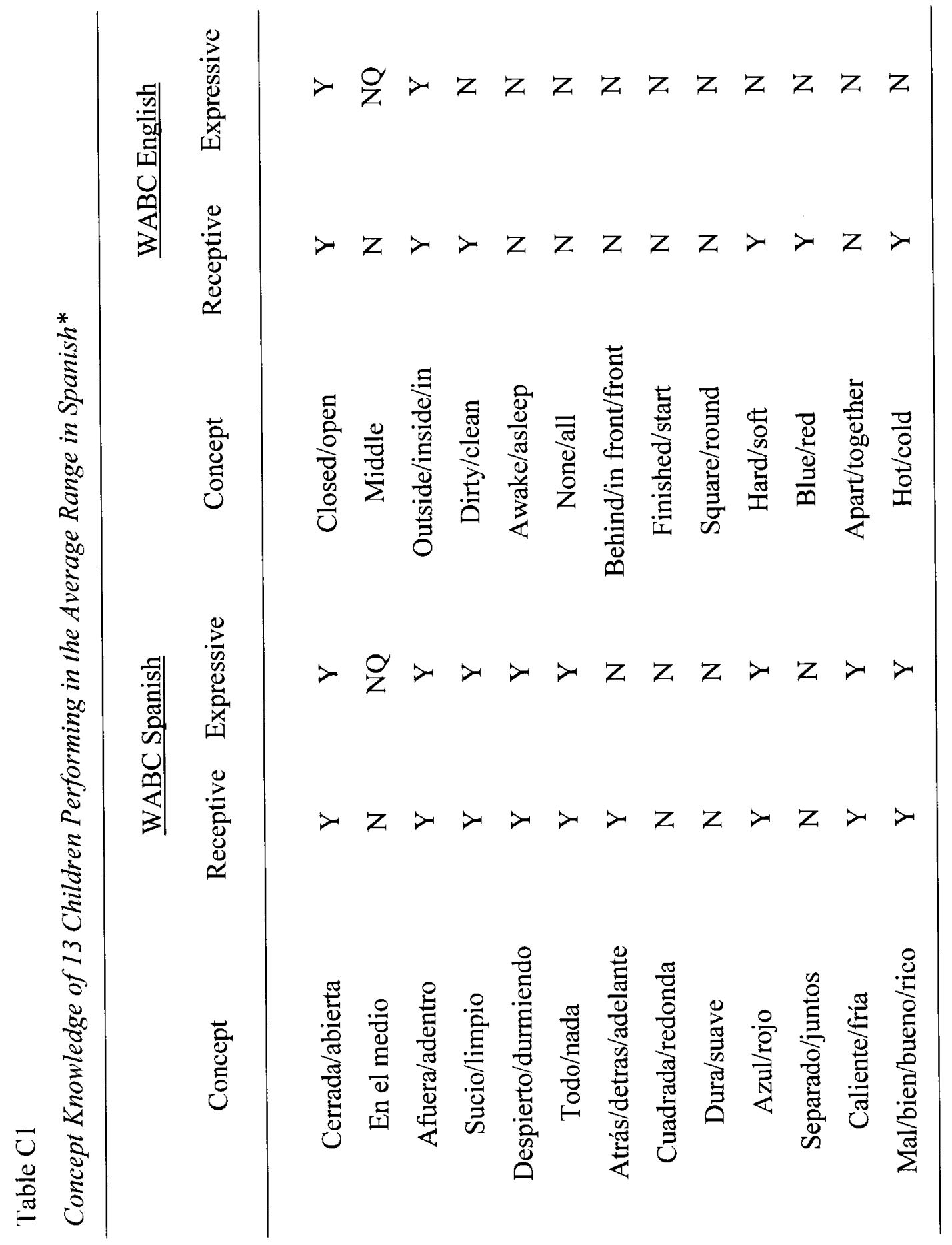




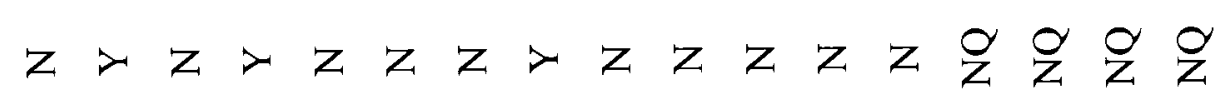

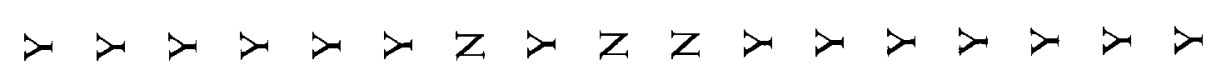

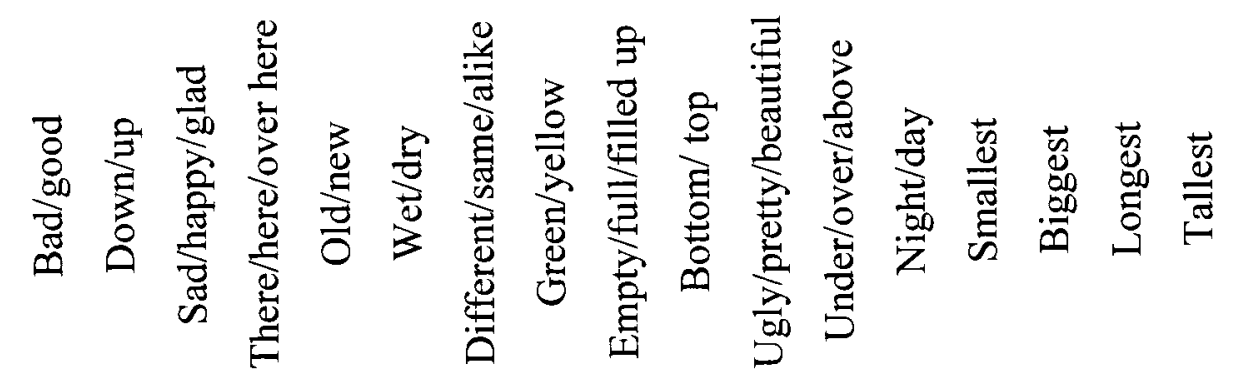

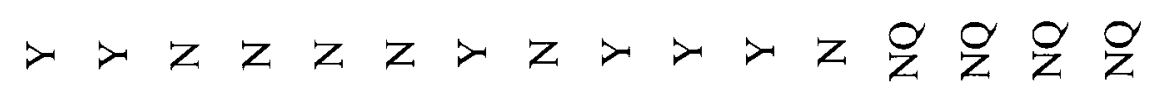

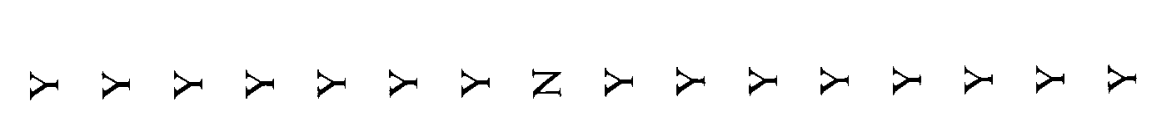

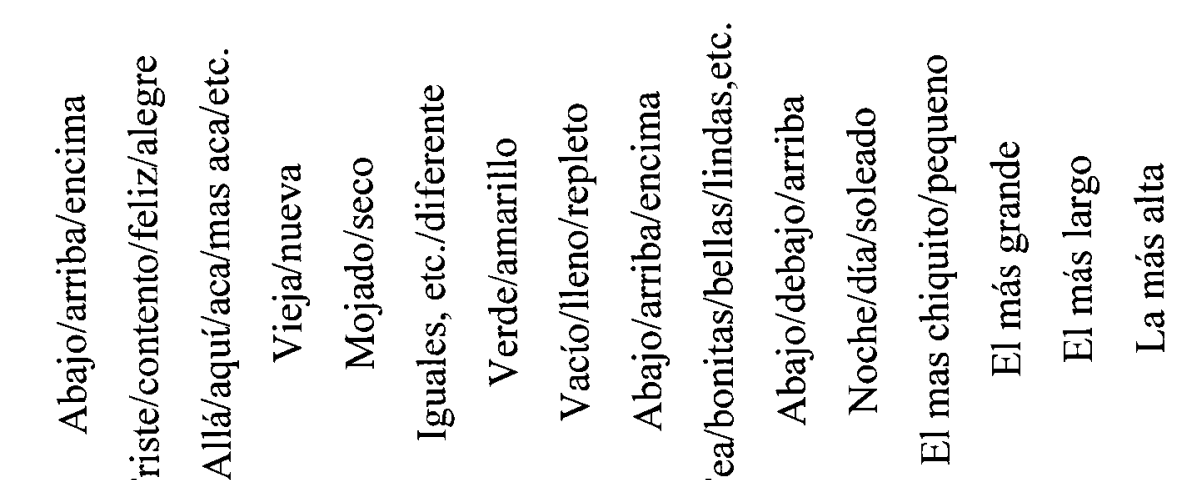

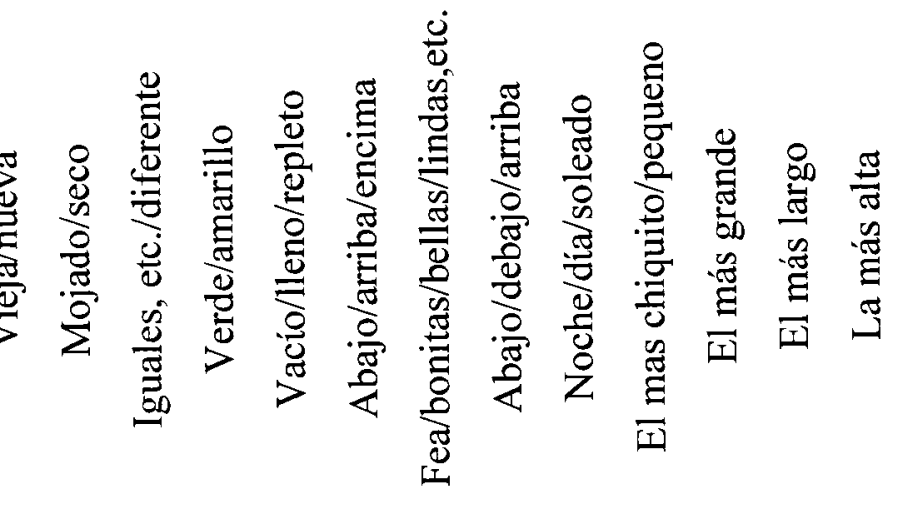

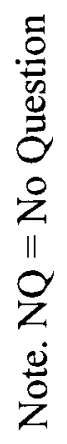




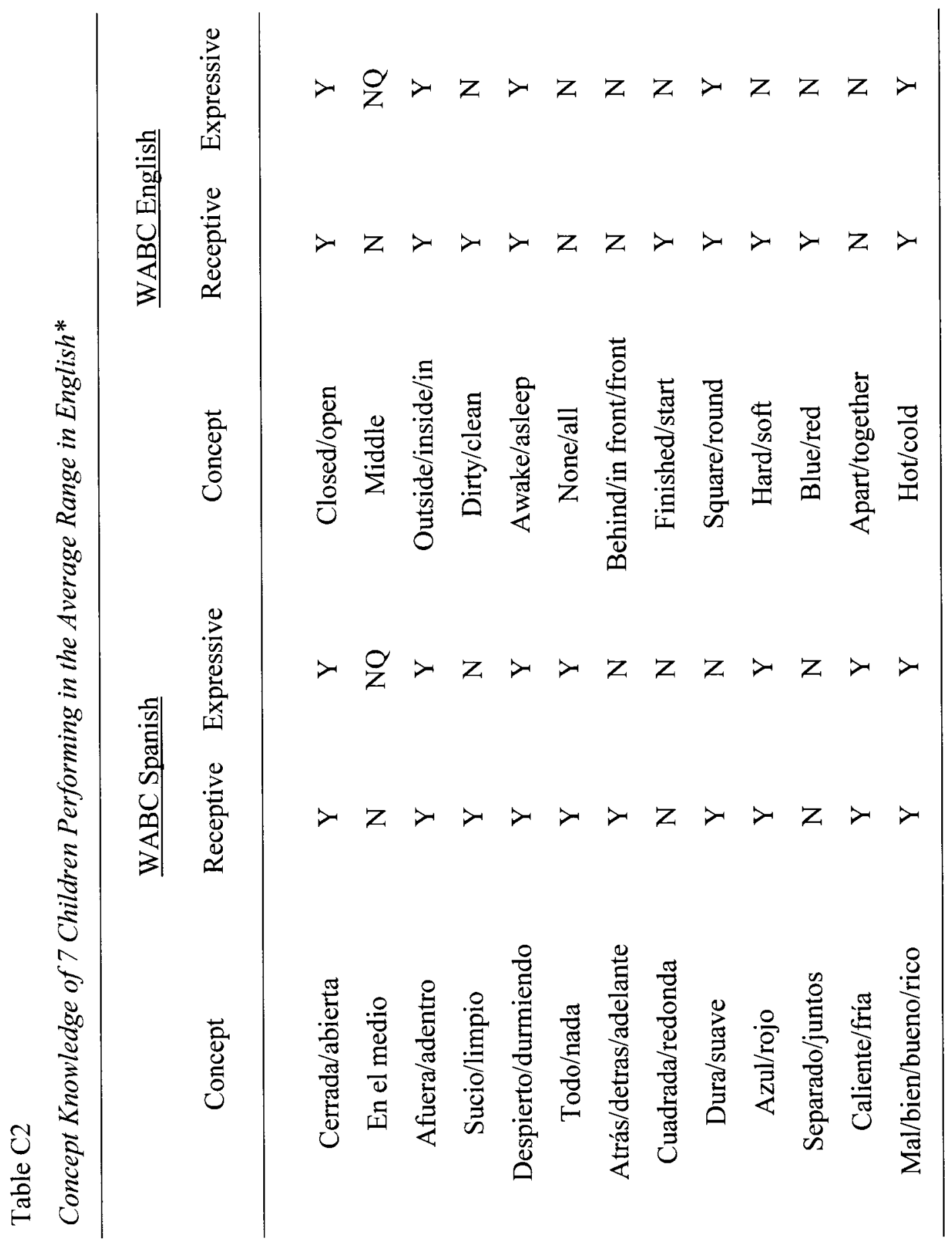


$z>>z z z z>z z z>z \& g q g$

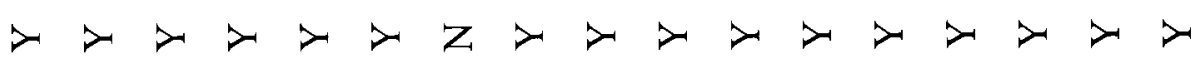

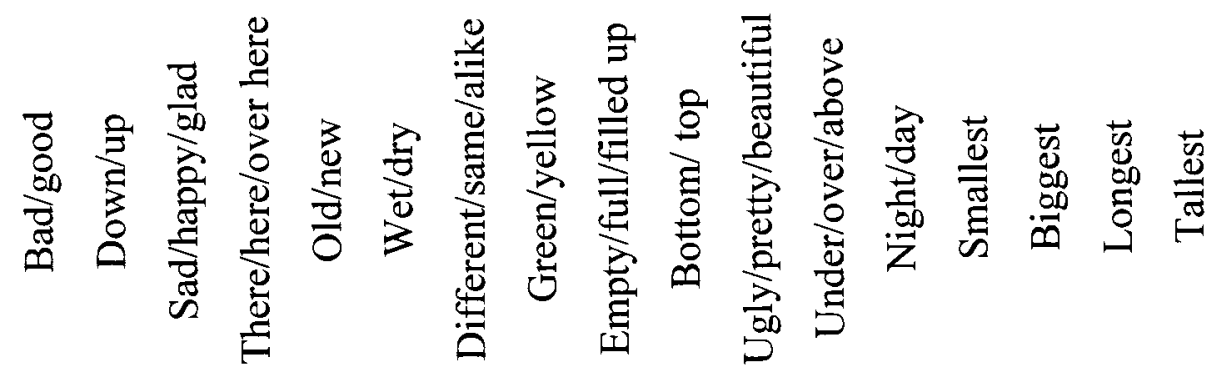

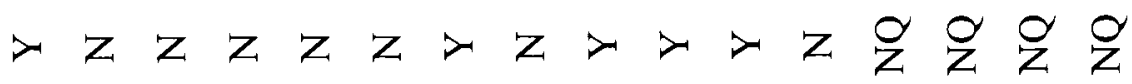

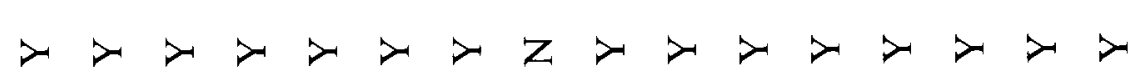

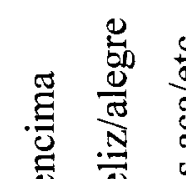

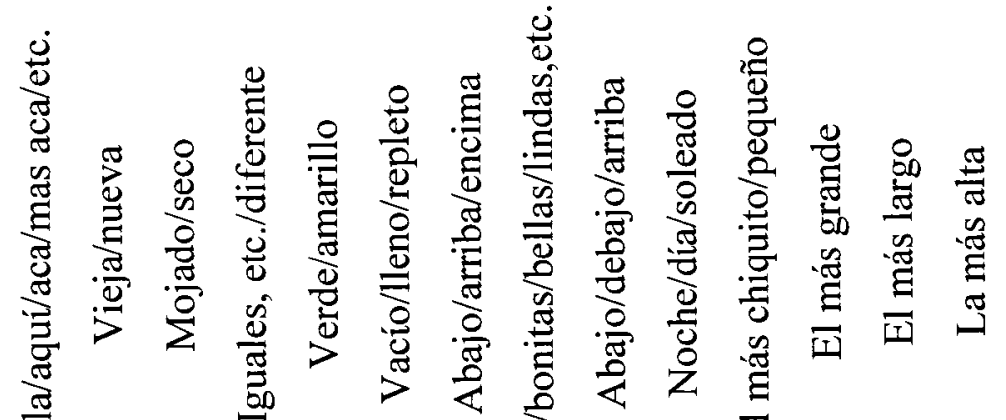

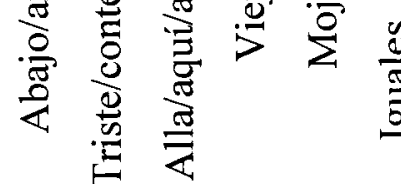




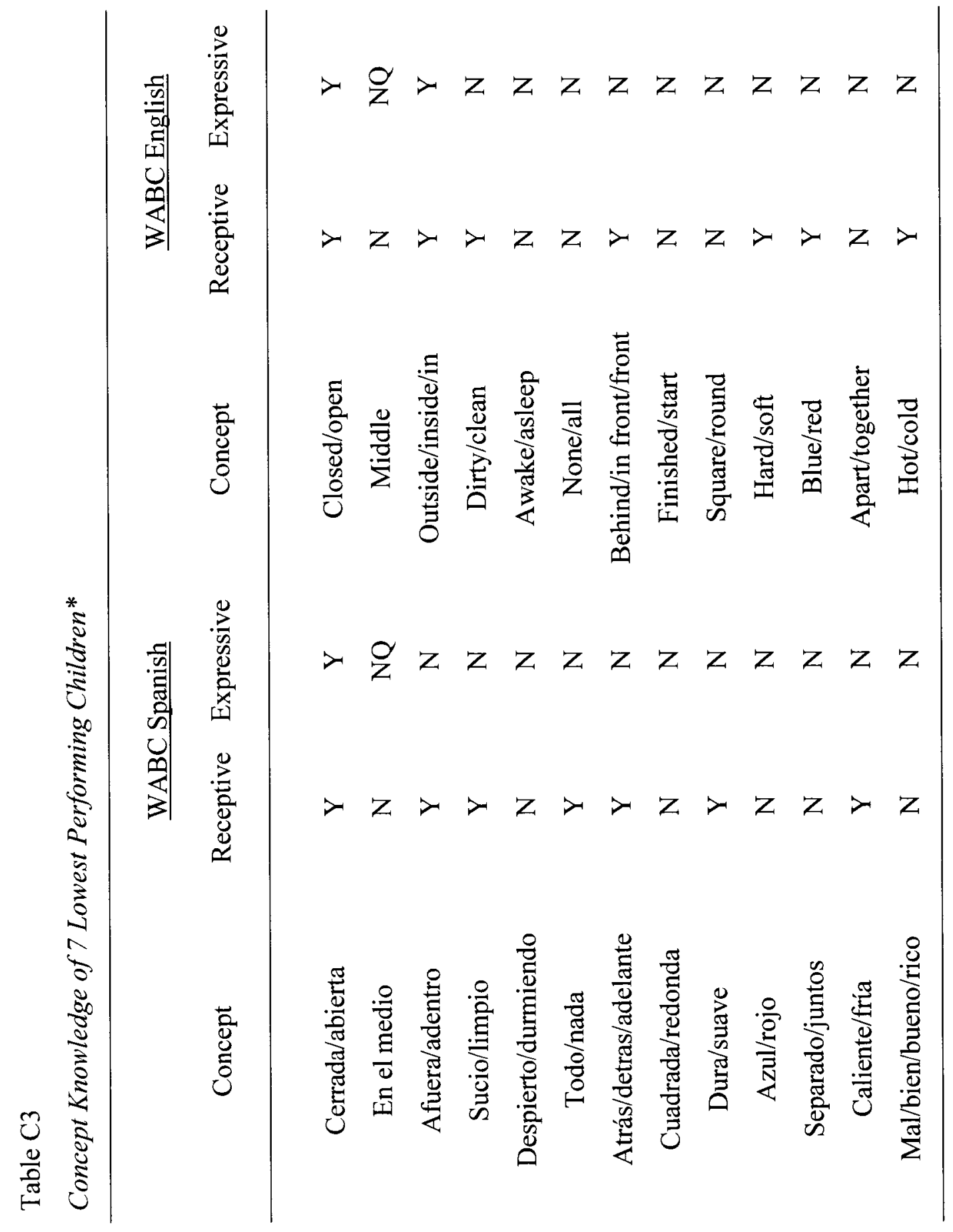


$z>z z z z z>z z z z z \underset{z}{g} \underset{z}{g} \underset{z}{q}$

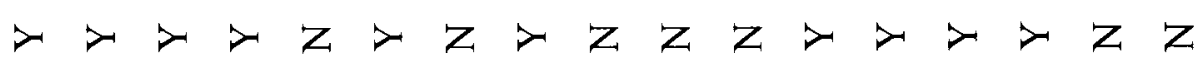

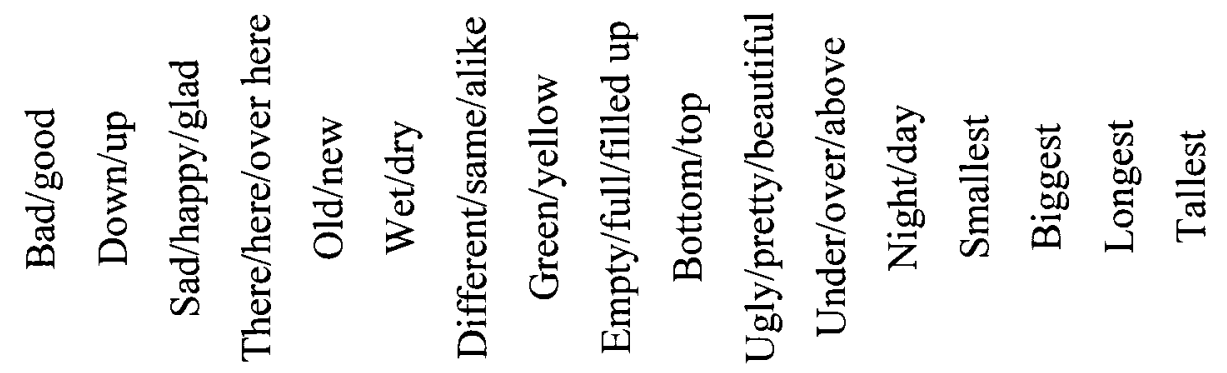

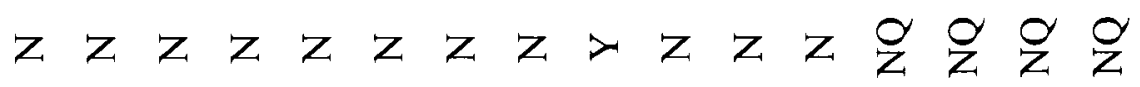

$z>>z>z z z>z>>>>z z$

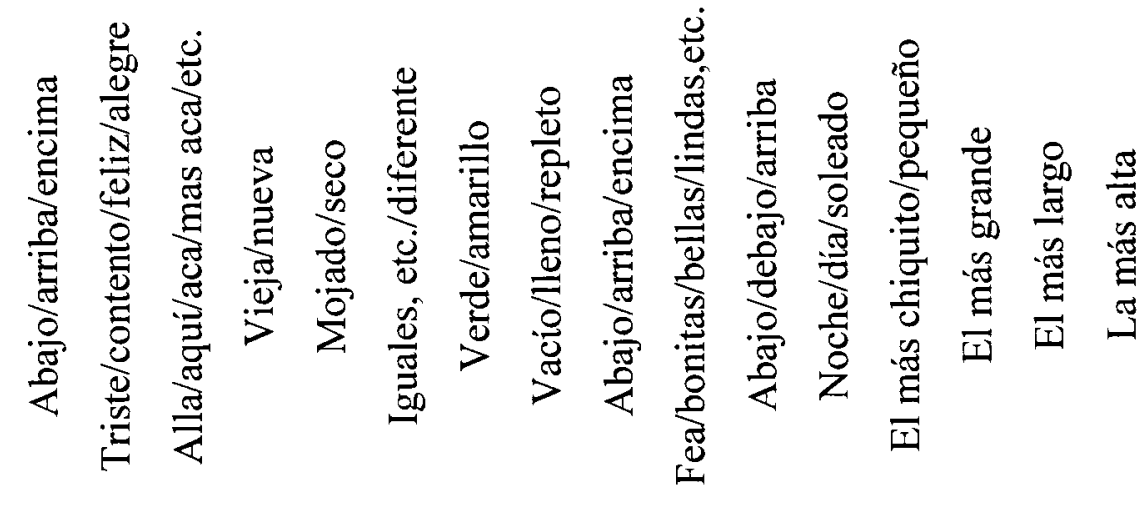

0
.0
0
0
0
0
0
$z$
0
0
$z$
0
0
$z$ 